\title{
Towards Teaching as Design: exploring the interplay between full-lifecycle Learning Design tooling and Teacher Professional Development
}

\author{
Juan I. Asensio-Pérez ${ }^{\mathrm{a}, 1}$, Yannis Dimitriadis ${ }^{\mathrm{a}}$, Francesca Pozzi ${ }^{\mathrm{b}}$, Davinia Hernández-Leo ${ }^{\mathrm{c}}$, Luis P. Prieto ${ }^{\mathrm{d}}$, \\ Donatella Persico ${ }^{\mathrm{b}}$, Sara L. Villagrá-Sobrino ${ }^{\mathrm{e}}$ \\ ${ }^{a}$ School of Telecommunications Engineering, Universidad de Valladolid, Paseo de Belén 15, 47011 \\ Valladolid, Spain, \{juaase, yannis\} @ tel.uva.es \\ ${ }^{\mathrm{b}}$ Istituto Tecnologie Didattiche (ITD) - CNR, Via de Marini 6, 16149 Genoa, Italy, \{poz zi, \\ persico\} @itd.cnr.it \\ ${ }^{c}$ Department of Information and Communication Technologies, Universitat Pompeu Fabra, Roc Boronat \\ 138, 08018 Barcelona, Spain, davinia.hernandez @upf . edu \\ ${ }^{\mathrm{d}}$ School of Educational Sciences, Tallinn University (TLU), Uus-Sadama 5, \\ 10120 Tallinn, Estonia, lprisan@tlu.ee \\ ${ }^{e}$ Faculty of Education and Social Work, Universidad de Valladolid, Paseo de Belén 1, 47011 Valladolid, \\ Spain, sarena@pdg.uva.es
}

\begin{abstract}
Recent research suggests that training teachers as learning designers helps promote technologyenhanced educational innovations. However, little attention has been paid so far to the interplay between the effectiveness of Teacher Professional Development (TPD) instructional models promoting the role of teachers as designers and the capabilities (and pitfalls) of the heterogeneous landscape of available Learning Design (LD) tooling employed to support such TPD. This paper describes a mixed method study that explores the use of a novel Integrated Learning Design Environment (ILDE) for supporting a TPD program on Information and Communication Technologies (ICT) and Collaborative Learning (CL). 36 Adult Education (AE) and Higher Education (HE) in-service teachers, with little experience on both CL and ICT integration, participated in a study encompassing training workshops and follow-up fulllifecycle learning design processes (from initial conceptualization to implementation with a total of 176 students). The findings from our interpretive study showcase the benefits (and required effort) derived from the use of an integrated platform that guides teachers along the main phases of the learning design process, and that automates certain technological setup tasks needed for the classroom enactment. The study also highlights the need for adaptation of the TPD instructional model to the learning curve associated to the LD tooling, and explores its impact on the attitude of teachers towards future adoption of LD practices.
\end{abstract}

Keywords: authoring tools and methods; distributed learning environments; improving classroom teaching; teaching/learning strategies.

\footnotetext{
${ }^{1}$ Corresponding autor. E-mail: juaase@tel.uva.es
} 
There is a growing recognition within the Technology-Enhanced Learning (TEL) research community of the importance of the role of teachers as designers (Kalantzis \& Cope, 2010; Laurillard, 2012; Goodyear \& Dimitriadis, 2013; Goodyear, 2015; Kali, McKenney, \& Sagy, 2015). Although the term teaching as design was coined back in 1989 (see Goodyear, 2015, for an account of its evolution) only in recent years the TEL community is paying more attention to the fact that "promoting best practice and effective pedagogy are at the very core of effective technology integration" (Ertmer \& Ottenbreit-Leftwich, 2013, p. 181). Teaching as design assumes that teaching quality largely depends on making the right pedagogical and technological decisions for providing more favourable conditions for effective learning with technology (Goodyear, 2015). Effectiveness, in this context, implies the use of "technology as a cognitive tool to develop critical thinking and higher-order skills" (Ertmer \& Ottenbreit-Leftwich, 2013, p. 181). Within TEL, supporting the role of teachers as designers using technological solutions is the main goal of the Learning Design (LD) field (Maina, Craft, \& Mor, 2015).

The LD field is theoretically underpinned by a sociocultural perspective (Conole, 2015) that not only considers design as context-based and influenced by the environment and background of the teachers, but also understands design as an activity mediated by artefacts. Such artefacts guide teachers' design processes and make design decisions explicit, sharable, and reusable within communities of teacherdesigners (Mor, Craft, \& Hernández-Leo, 2013). Consequently, a significant part of LD research focuses on developing mediating artefacts such as authoring tools and interoperable computational representations of teachers' designs (typically called learning designs) (see, e.g., Prieto et al., 2013a; Celik \& Magoulas, 2016), as well as technological solutions for promoting practices of sharing and reuse of TEL innovations (Hernández-Leo et al., 2011; Agostinho, Bennett, Lockyer, Jones, \& Harper, 2013). These research efforts are complemented with empirical studies that suggest that LD can help teachers innovate in their practices and incorporate new pedagogical approaches such as those based on constructivist theories (Dobozy, 2013). Similarly, recent proposals point out the complementary relationship of LD with TPACK (Technological, Pedagogical, Content Knowledge), a well-established theoretical framework that "describes the kinds of knowledge needed by a teacher for effective technology integration" (Koehler, Mishra, Kereluik, Shin, \& Graham, 2014, p. 101). For instance, Dobozy and Campbell (2016) argue that LD can help develop teachers' TPACK in actual design practice. Also, Boschman, McKenney, and Voogt (2015) suggest that TPACK develops when teachers reflect on the actions taken during their design processes. All in all, the gradual adoption of LD tools and practices seems to be a promising approach for helping teachers improve the way they integrate both technology and innovative pedagogy in their classrooms.

However, and in spite of more than a decade of research (Dalziel et al., 2013), LD has not widely impacted teaching practice yet (Bennett, Agostinho, \& Lockyer, 2017). Some authors argue that existing LD tools need to overcome three main barriers (Voogt et al., 2011; Mor et al., 2013; Bennett et al., 2015; Pozzi, Ceregini, Dagnino, Ott, \& Tavella, 2015): 1) LD tooling should provide higher flexibility, for example allowing the integration of different existing solutions; 2) should provide support to all the phases of a design process (from conceptualization to actual enactment with learners); 3 ) and, should also support and scaffold communities of (co)designers. However, other authors shift the focus from the LD tooling and underline the challenge of equipping teachers with the appropriate LD mindset for making 
design decisions in their often unpredictable classroom contexts (Dimitriadis \& Goodyear, 2013; Kali et al., 2015). Bennett, Agostinho, \& Lockyer (2017) point out that "appropriate training and supports will be needed and will need to be adopted much more widely" (p. 143) in order for teachers' design to become a driver of innovation. Such a challenge underlines the importance of a "massive project of (teacher) professional development" (Maina et al., 2015, p. xvii) to promote the uptake of LD tools and practices.

Recent literature is starting to synthesize the wide corpus of research that explores how teachers design and what type of support they would need for becoming effective designers. Thus, for instance, McKenney, Kali, Markauskaite, and Voogt (2015) propose an ecological framework for conceptualizing the knowledge teachers would need to productively engage in design. Similarly, Svihla, Reeve, Sagy, and Kali (2015), identify a fingerprint pattern of common elements in previous research proposals for Teacher Professional Development (TPD) in the design of TEL innovations. Interestingly, many of the existing proposals for TPD programs that involve LD tools and practices are focused on the influence of TPD instructional models in changing teachers' beliefs towards TEL innovation and in shaping their identity as designers (Svihla et al., 2015; Bjælde, Caspersen, Godsk, Hougaard, \& Lindberg, 2015; Sagy \& Kali, 2014; Prieto, Dimitriadis, Asensio-Pérez, Jorrín-Abellán, \& Villagrá-Sobrino, 2013b; Mor \& Mogilevsky, 2013). However, less attention is been paid to the role of the LD tools (e.g., authoring environments, LD representations, etc.) used in those TPD programs, as well as their interplay with the instructional model applied in each case. Indeed, in many of the reported TPD programs, a wide range of general-purpose tools is used by teachers for carrying out the assigned design tasks: those provided by mainstream Virtual Learning Environments (VLEs) such as Blackboard (Bjælde et al., 2015) or Moodle (Kali \& Ronen-Fuhrmann, 2011), shared documents editors such as Google Documents (Svihla et al., 2015), wiki-like editors such as Google Sites (Sagy \& Kali, 2014), or even plain web sites (Mor \& Mogilevsky, 2013). One example of the few studies in which LD-specific tools were employed in a TPD programs is Prieto, Tchounikine, Asensio-Pérez, Sobreira, \& Dimitriadis (2014) but, again, the focus of the research intervention is not on the influence of such tools in the effectiveness of the TPD approach. This apparent scarcity of studies about the role of LD purpose-specific tooling in TPD seems conflicting with the abovementioned importance of mediating tools in design activities (Conole, 2015) and the identified need of flexible LD tooling with community support for improving the chances of LD uptake (Bennett et al., 2015; Persico, Milligan, \& Littlejohn, 2015).

Therefore, this paper addresses the following research question: what are the main features of the interplay between LD tooling and TPD programs aimed at training teachers as designers? Thus, the paper describes a study performed around a TPD program in which 36 Adult Education (AE) and Higher Education (HE) in-service teachers participated in 2 training workshops on the use of LD tools and practices for designing and enacting Collaborative Learning (CL) teaching innovations with ICT. After the workshops, 8 teachers completed a whole learning design process and enacted their designs with a total of 176 students. The study, from an interpretive perspective, focuses on how a novel web-based community environment named ILDE (Integrated Learning Design Environment) supported the participants of the TPD program (who were inexperienced in LD, CL and/or learning technologies) as they strived to design and enact technology-enhanced CL situations. The interest of the study lies in the fact that the ILDE is an environment that tries to overcome the three main aforementioned barriers for adoption of current LD tooling: 1) the ILDE provides a single access point to a variety of different, yet complementary existing LD tools, thus providing flexibility for the designers; 2) the ILDE supports 
teachers along a full-lifecycle learning design process that goes from ideation of innovations to their enactment with actual students; 3) and, the ILDE incorporates a set of social features to support communities of co-designers. Thus, the study tries to understand how those ILDE features are used and perceived by teachers when taking part in a specific TPD program, and whether those features complement or collide with the instructional model of the TPD itself. The findings from the study can be relevant for researchers interested in TPD for the integration of ICT, due to several reasons: they can help understand the interplay between TPD models and the LD tools they employ; they can point out salient ILDE features that might make it suitable to other TPD programs also focused on the role of teachers as designers; and, they refer to a population of in-service teachers without previous formal training in innovative pedagogies and the use of ICT for learning, thus posing additional challenges for their professional development when compared, e.g., with pre-service primary school teachers.

The structure of the paper is as follows: section 2 provides an overview of the ILDE and describes in more detail the TPD model employed in the study; section 3 describes the context, method and main results of the study; finally, section 4 discusses the main conclusions from the presented research work and potential future research lines.

This section has two goals: to provide an overview of the ILDE, emphasizing how it tries to overcome several of the main limitations found in the current landscape of LD tooling (subsection 2.1), and to introduce a TPD instructional model that leverages several best practices identified in the literature, and promotes the adoption of LD practices for teaching innovation among inexperienced teachers (subsection 2.2). The interplay between the ILDE and the structure of the TPD model is one of the key aspects of subsection 2.2, and will be the focus of the research study presented in the paper.

\subsection{The Integrated Learning Design Environment (ILDE)}

The Integrated Learning Design Environment (ILDE) (Hernández-Leo, Asensio-Pérez, Derntl, Prieto, \& Chacón, 2014) is a web platform ${ }^{2}$ that provides support to communities of educational designers (mostly teachers as designers, but also, e.g., professional instructional designers) in the process of co-creating and sharing learning designs. The ILDE integrates a wide variety of existing LD tools and representations to support designers at different moments during their learning design processes. Indeed, the ILDE does not prescribe a unique learning design pathway for all its users. On the contrary, the ILDE features an open architecture aimed at integrating as many LD tools as possible so that designers can decide which ones are best suited for their specific goals and previous design practices. Although the ILDE acknowledges this need for flexibility in terms of tools and processes (Bennet et al, 2015), it groups the integrated tools in three sets that correspond to three main phases, commonly found in several learning design processes discussed in the literature (Pozzi, Asensio-Pérez, \& Persico, 2016): Conceptualization, Authoring and

\footnotetext{
${ }^{2}$ A demo installation of the ILDE can be accessed at http://ilde.upf.edu, Last visited: January, 2017.
} 
Implementation. The support to those three phases by a single platform (a full-lifecycle learning design process), using different combinations of tools and representations, is another distinctive feature of the ILDE and one of the pursued goals of the LD research community (Maina et al., 2015).

This full-lifecycle process typically begins with the conceptualization phase where the teachers analyse the educational context in which to apply the desired innovation, define the learning goals, identify main blocks of learning activities, or characterize the different types of stakeholders (student types, teaching assistants, etc.). During this phase, the ILDE provides teachers with a variety of textual or graphical templates, most of which were proposed in previous LD-related initiatives such as the Learning Design Studio (Mor \& Mogilevsky, 2013), the OULDI project (Cross, Galley, Brasher, \& Weller, 2012), or the LD-GRID project ${ }^{3}$. Figure 1 shows screenshots of two conceptualization templates available in the ILDE: the Persona Card that helps teachers reflect on the characteristics of the different roles involved in a learning scenario, and the Dream that guides teachers through the process of making explicit the motivation and the way of approaching a pursued teaching innovation.

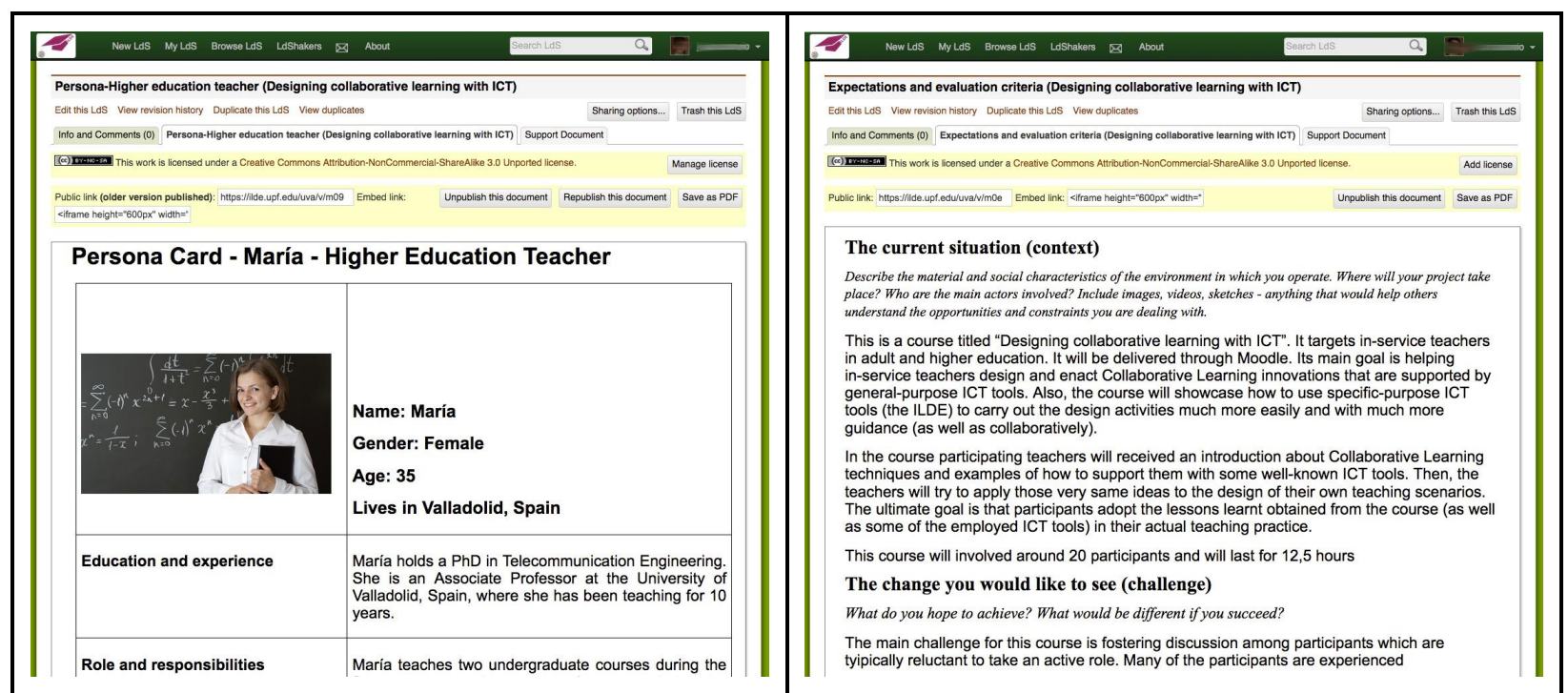

Figure 1. Screenshots of the ILDE showing the Persona Card (left) and Dream (right) conceptualization templates.

After conceptualizing their learning scenarios, teachers can start the authoring phase: the process of producing full-fledged definitions of learning designs that include the flow of activities and associated resources that students are intended to follow. Learning designs produced in the authoring phase are not bound to a specific cohort of students nor to a particular technological enactment platform, and are therefore reusable in different teaching settings. The ILDE integrates several existing LD authoring tools that represent learning designs in computer-interpretable formats using teacher-friendly graphical metaphors. For instance, WebCollage (Villasclaras-Fernández, Hernández-Leo, Asensio-Pérez, \& Dimitriadis, 2013) and OpenGLM (Derntl, Neuman, \& Oberhuemer, 2011) use internally the IMS LD specification (IMS Global Learning Consortium, 2003), while CADMOS (Katsamani \& Retalis, 2011)

${ }^{3}$ http://http://www.ld-grid.org, Last visited: January, 2017. 
employs a Microsoft Word-derived XML representation. The rationale for choosing computerinterpretable representations of the learning designs relies on the possibility of automating the setting up of the technological platform for the enactment (see the implementation phase below). It is also worth underlining that some of the integrated LD authoring tools are better suited to specific pedagogical approaches. Thus, for instance, the WebCollage authoring tool (see Figure 2) is aimed at supporting teachers in the design of Collaborative Learning (CL) situations based on the particularization of a combination of best practices (or patterns) for structuring the flow of CL activities (Hernández-Leo, Villasclaras-Fernández, Asensio-Pérez, \& Dimitriadis, 2009).

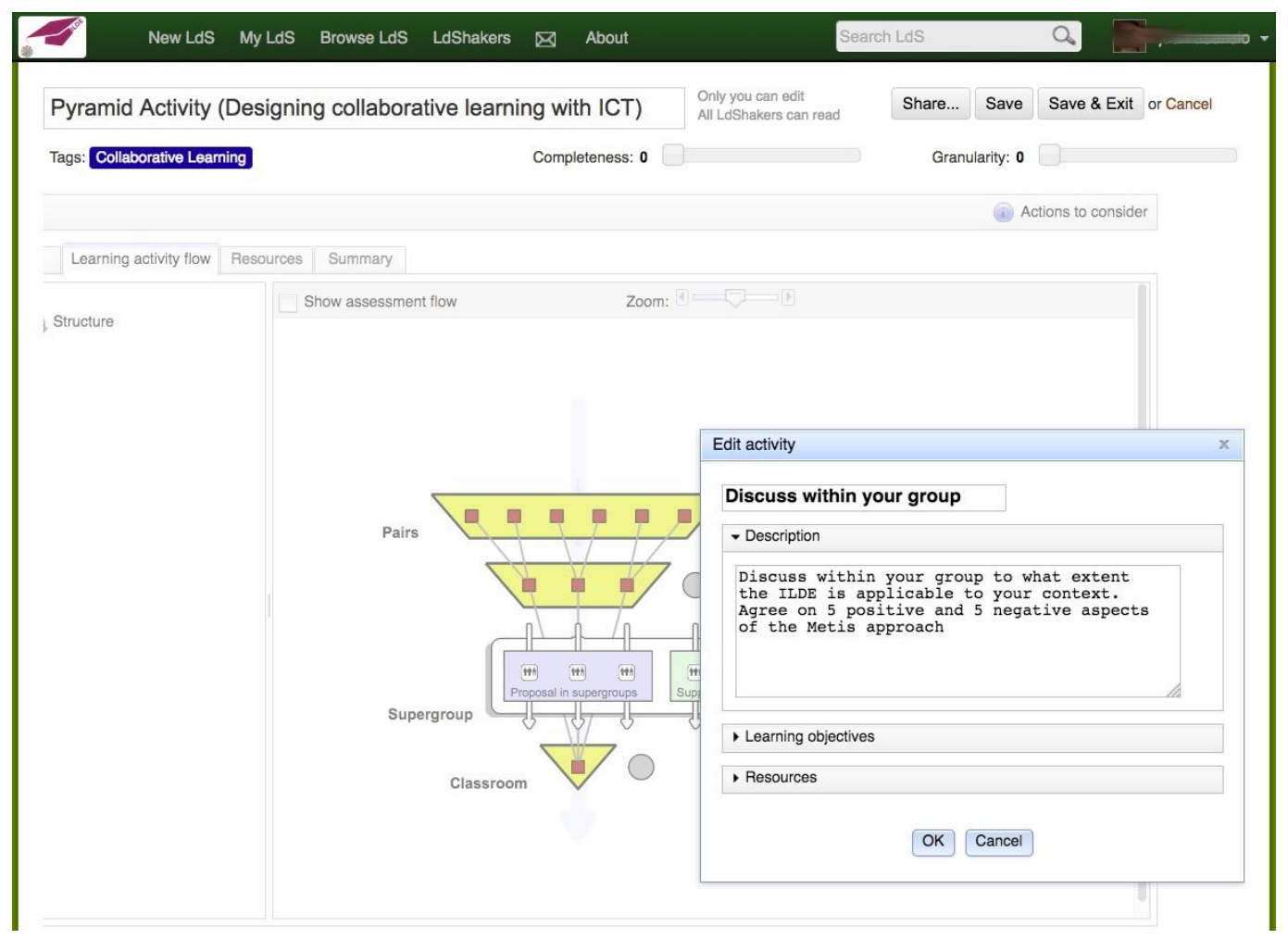

Figure 2. Screenshot of the ILDE showing the WebCollage authoring tool (the screenshot shows a design based on the pyramid or snowball well-known collaborative learning pattern).

The final step of the ILDE full-lifecycle design process is the implementation phase. In this phase the ILDE uses the GLUE!-PS (Group Learning Unified Environment - Pedagogical Scripting) system (Prieto et al., 2013c) to automatically set up the technological platform for the enactment of the learning design (e.g., a Learning Management System such as Moodle), following teachers' instructions as reflected in the computer-interpretable authored designs. The ILDE is capable of implementing teachers' designs in a variety of mainstream Virtual Learning Environment or VLEs (e.g., Moodle, MediaWiki,...), also giving the possibility of integrating several third-party web 2.0 tools (e.g., Google Drive tools) by means of the GLUE! (Group Learning Unified Environment) System (Alario-Hoyos et al., 2012). During the implementation with the ILDE, teachers first bind an authored learning design with a specific course of the target VLE. Then, teachers use the GLUE!-PS Graphical User Interface (GUI - see Figure 3, top) to: 1) assign students enrolled in the course to the different groups envisioned in the authored design; and, 2) specify which ICT tools (offered by the VLE and the third-party web 2.0 tools it integrates) should be 
used by students in the different designed activities during enactment. Finally, the ILDE automatically sets up and configures the target VLE reflecting the contents of the implemented learning design (Figure 3 , bottom).

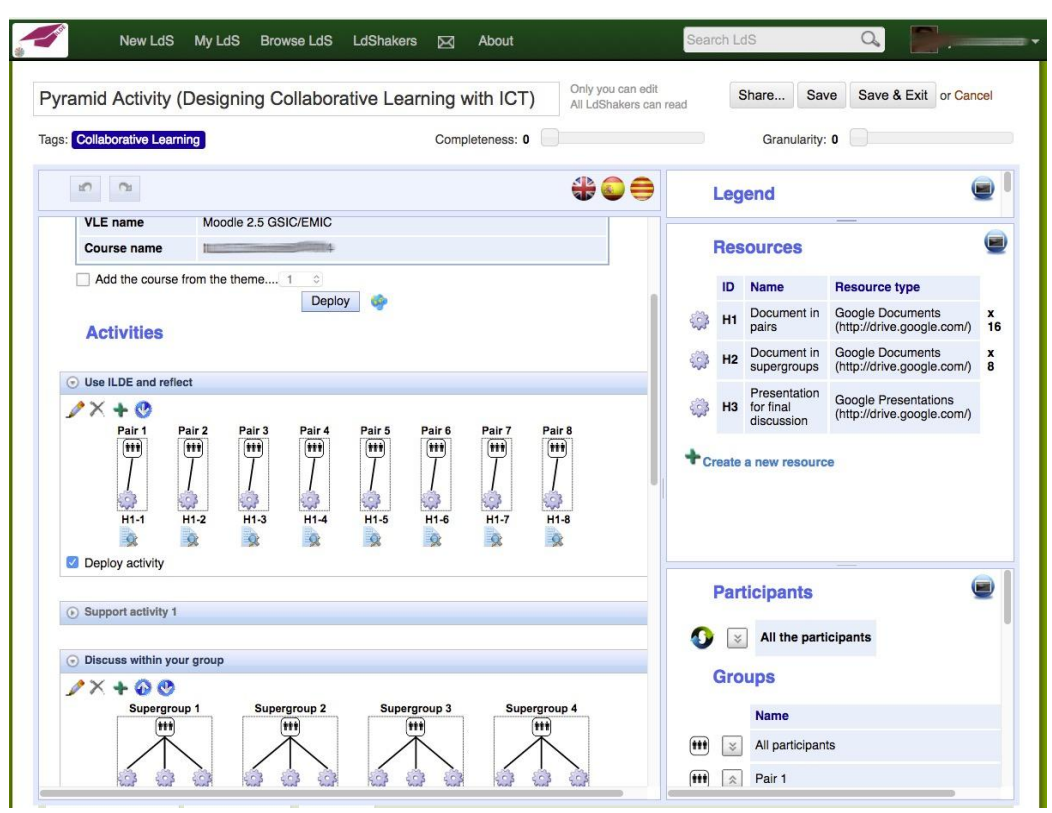

group - Document in supergroups (Supergroup 1)

Discuss within your group to what extent the ILDE is applicable to your context. Agree on 5 positive and 5 negative aspects of the Metis approach.

If you can not see the resource in the frame below, click on the link to open it: Supergroup - Discuss

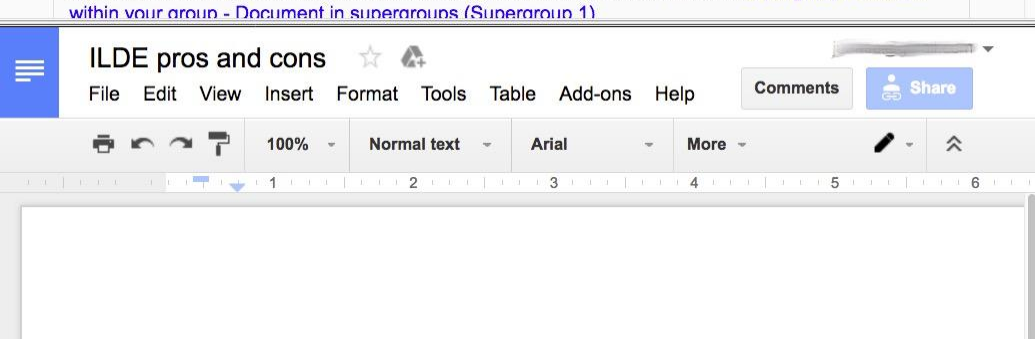

Pros

- Integrated tools

- Easy to use

- Posting comments

- Revision

- Reflection

Cons

- Terminology

- From WebCollage to Glue!PS

Figure 3. Screenshot of the ILDE showing the GLUE!-PS GUI for implementation (top) and screenshot of Moodle showing the automatically implemented course that integrates third-party web 2.0 tools, in this case a Google Document (bottom). 
All the above mentioned learning design phases supported by the ILDE are complemented by a set of community features provided by the LdShake system (Hernández-Leo et al., 2011) that allow designers to: share their learning designs with other ILDE users granting viewing or editing rights; annotate and tag own or others' learning designs; create groups of ILDE users involved in specific co-design projects; browse and/or search for others' designs; duplicate and control the versioning of own or others' learning designs (Chacón-Pérez, Hernández-Leo, Mor, \& Asensio-Pérez, 2016).

\subsection{An ILDE-supported TPD model for Collaborative Learning}

The study presented in this paper is focused on a TPD instructional model for HE and AE in-service teachers titled ICT tools for Collaborative Learning. The main goal of the TPD model is that teachers learn how to design and enact CL situations using ICT tools. This approach puts the emphasis on "how to implement powerful instructional methods" (based on CL) using technology in a supportive role (Ertmer \& Ottenbreit-Leftwich, 2013, p. 180). The ICT support for CL is showcased using mainstream Virtual Learning Environments (e.g., Moodle) combined with web 2.0 tools (e.g., those provided by Google Drive). The ILDE is expected to support all design activities envisioned by the TPD model.

The TPD model is divided in two main phases (see Figure 4). The first phase (workshop phase) consists of a teacher training workshop (suggested target audience: 20 participants, estimated duration: no longer than 15 hours), blending face-to-face and remote activities, with the following structure:

1. Introduction to the rationale for $\mathrm{CL}$ followed by a description of well-known CL techniques described in the form of patterns (Hernández-Leo et al., 2009).

2. Presentation of the potential advantages of LD, together with the need for ICT tools, such as the ILDE, capable of supporting teachers along a full-lifecycle learning design process.

3. Tour of ILDE main features, including those aimed at sharing design artefacts and community support. Participants are expected to explore different conceptualization and authoring LD tools available within ILDE.

4. Participants carry out a complete design cycle (including its implementation in a VLE and accompanying web 2.0 tools) of a sample CL scenario, based on one or several CL patterns, using detailed step-by-step documentation (manuals, worksheets, ...). Participants then experience themselves, in the role of students, the pedagogical approach and ICT tools employed in the sample CL scenario.

5. Participants apply the same design process, supported by the ILDE, to a CL situation within the participants' teaching context. Participants are expected to select one or several CL patterns as the basis for their design.

6. Participants peer-review their design projects using ILDE community features. Their reviews are then discussed in a plenary debate to draw the main final lessons learnt from the workshop.

For steps 4 and 5 above, participants are expected to use the Dream and Persona Card templates for the conceptualization phase of the design processes (see section 2.1). These templates are aimed at helping teachers reflect, in general terms, on the where (context), why (challenge), how (learning activities), and who (roles) of their design. For the authoring phase of the design process, WebCollage is the tool of 
choice, since it is specifically suited for CL and because it enables teachers to base their designs on the CL patterns that were introduced in step 1.

This workshop phase is the result of more than a decade of experience of four of the authors of this paper in similar TPD programs on CL and ICT. In the first editions only LD authoring tools such as Collage or WebCollage were employed (Hernández-Leo et al., 2006; Villasclaras-Fernández et al., 2013). In more recent instances of the workshop the support for implementation was also provided, although not integrated in a single platform (Prieto et al., 2013b; Prieto et al., 2014). Additionally, in the early workshop editions, the conceptualization was not supported by LD tools, neither did participants peerreviewed their designs using community features.

The second phase of the TPD program (follow-up phase) involves volunteer participants from the training workshops that engage in an improvement of their own designs. Participants are expected to work individually or in design teams, potentially formed with other teachers than did not participate in the first workshop phase. The follow-up phase is again supported by the ILDE, providing the same tools that were employed in the workshop phase, and facilitated by the TPD program instructors through periodic faceto-face meetings or online interactions (via email or by means of ILDE community-support features). Final, mature designs are automatically implemented by the ILDE in the supported learning platform of choice and then enacted with actual students. The duration of this phase depends on the contextual restrictions of each design team, but is not expected to last longer than a semester.

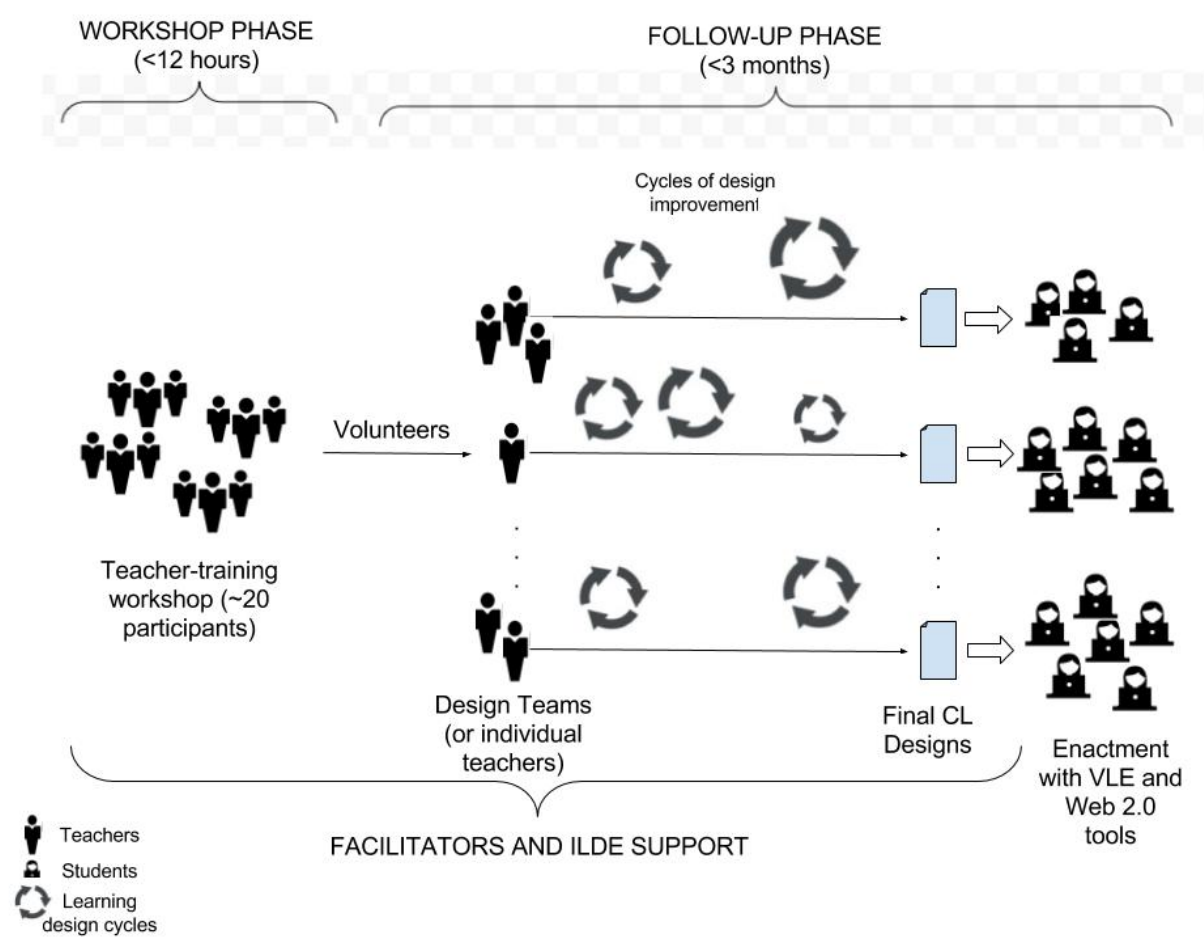

Figure 4. The ILDE-supported TPD model used in the study.

The TPD model described above draws on several proposals and recommendations reported in the literature. For example, Kali \& Ronen-Fuhrmann (2011) suggest structuring the design process so as to 
help participants concretize their design ideas, building on accessible repositories of expert design knowledge, and enabling dialogic learning (following the ADDIE - Analysis, Design, Development, Implementation, Evaluation - approach from Branch, 2009). In the case of the TPD model described in this section, the ILDE conceptualize/author/implement full-lifecycle gives structure to the design process, the CL patterns provide expert design knowledge, and the social features of the ILDE enable sharing and review of design ideas and proposals. In another related work, Murthy, Iyer, \& Warriem (2015) propose the use of their so-called A2I model (Attain-Align-Integrate) for TPD, underlining the importance of using examples in which participants can play the student role. They also stress the benefits of blending face-to-face and asynchronous online sessions so as to provide participants with enough time for reflecting on how to apply the workshop contents to their own practice (see also Delfino \& Persico, 2007). Both aspects are also incorporated to the ILDE-supported TPD model. Similarly, the follow-up phase has many elements in common with the Learning Design Studio (Mor \& Mogilevsky, 2013) where participating teachers engage in a design project that addresses a specific educational challenge, and where facilitators provide continuous guidance throughout the design process. Finally, the described TPD model incorporates best practices for design-focused TPD programs as identified by the "fingerprint pattern of supports for teachers' designing of technology-enhanced learning” (Svihla et al., 2015, p. 283): modelling practice (jigsaw and peer-review CL patterns are applied for structuring the activities of the workshop phase); supporting dialogue (interactions among participants and with facilitators are fostered and supported by means of the ILDE community features); scaffolding the design process (conceptualization templates and CL patterns provide experts' design knowledge that participating teachers use as starting points for the own design projects); and designing for real-world use (workshop participants are expected to design CL situations framed within their own courses, and the teachers taking part in the follow-up phase are even expected to use their design with actual students in authentic contexts).

The main novelty of this TPD program lies in the use of the ILDE as a single, integrated platform for fulllifecycle LD that mediates all design activities and participants' interactions. Additionally, the TPD program audience is not necessarily limited to pre-service teachers with pedagogical background, as in previous approaches (Mor \& Mogilevsky, 2013; Kali \& Ronen-Fuhrmann, 2011). Indeed, participants might have no previous experience in applying CL techniques and in integrating ICT tools in their teaching practice, which is especially challenging. This is the reason why only a predefined subset of ILDE tools are presented to the participating teachers, rather than allowing them to select a preferred combination of design tools aligned with their previous expertise. In the spirit of the ecological framework for conceptualizing teacher design knowledge for TEL, our TPD model is focused on transferring "powerful design heuristics that can increase the efficiency and effectiveness of teachers' design work" (McKenney et al., 2015, p. 191), instead of accommodating "teacher-designer consciousness and situated experience" (McKenney et al., 2015, p. 195). In order to understand the interplay of the technological support (ILDE) in such professional development model, the following section presents a study carried out around a set of instances of the described TPD approach. 
The research question addressed by this study can be formulated as follows: what are the main features of the interplay between LD tooling and TPD programs aimed at training teachers as designers? The study is framed within an interpretive research paradigm (Orlikowski \& Baroudi, 1991) since it seeks a deep understanding of the particularity and the richness of the concrete phenomena under study, in this case the aforementioned interplay between LD tooling and TPD models. The study, exploratory in nature, focuses on one particular teacher training context, supported by the ILDE (see section 2.1) and structured according to a specific TPD instructional model (see section 2.2), which is approached in conditions as authentic as possible, mostly relying on qualitative evidence, and not pursuing statistically-significant results or generalizations (Guba, 1981). Consequently, the research question is contextualised within the presented study by defining the following issue that will guide the interpretation of the data (Stake, 2010): How does the ILDE contribute to the TPD program aimed at training teachers as designers of collaborative learning situations supported by ICT?

\subsection{Context}

The study was carried out in the context of a TPD program following the instructional model, presented in section 2.2 about ICT tools for Collaborative Learning. The TPD program, supported by the ILDE, was instructed by two of the authors of this paper and involved teachers from two educational contexts. On the one hand, 16 AE teachers from the Valladolid Province administration (Spain) enrolled in a workshop phase with a total duration of 4 hours, in a single face-to-face session that took place in September $2014^{4}$. According to a profiling questionnaire ([QuestPre-HE-WS], see next subsection for a description of the data sources employed in the study), the AE teachers came from a variety of disciplines (law, languages, engineering, ...), they all had Bachelor degrees, and their teaching experience was significant (Mean=16.7 years, $\mathrm{SD}=5.5$ years). On the other hand, $20 \mathrm{HE}$ teachers from the University of Valladolid (Spain) participated in a workshop phase, also in September 2014, that lasted 12.5 hours (two 4-hour face-to-face sessions, separated by a week, and 4.5 hours of estimated remote tasks). The HE workshop phase was framed within the official Teacher Training program of the University of Valladolid, where participation is voluntary. The workshop phase was instructed by the same two researchers. The HE teachers answered to the same profiling questionnaire as the AE teachers ([QuestPre-AE-WS], see next subsection), showing that they were also heterogeneous from the perspective of the disciplines they teach, that most of them held a doctoral degree, and that their teaching experience was rather varied (Mean=13 years, $\mathrm{SD}=7.85$ years).

Also according to the answers to the profiling questionnaires, both $\mathrm{AE}$ and HE participants tended to have a positive attitude towards CL, but they recognized that its use in their regular teaching was rather low. Furthermore, the use of ICT for supporting CL was even lower (see Table A.1 in the Appendix for more detailed data obtained from the profiling questionnaire).

Once the workshop phase finished, several volunteer teachers showed their interest in participating in the follow-up phase: 2 design teams and 3 individual designers (in the following, for the sake of brevity, we will refer to them all as 5 design teams) involving a total of 8 teachers. In two of those design teams there

\footnotetext{
${ }^{4}$ The duration of the workshop phase was adapted to conform with the local TPD actions within this context, thus spanning only a single morning and limiting the design activities of the participants to a sample CL scenario.
} 
were also teachers that had not participated in the workshop phase, but they were part of the teaching teams of the involved courses. Table 1 describes the five design teams, as well as the CL situations they designed during the follow-up phase.

Table 1. Description of the design teams that participated in the follow-up phase and of the teaching contexts in which they enacted the teaching innovations designed with the ILDE.

\begin{tabular}{|c|c|c|c|c|c|}
\hline Context & $\begin{array}{l}\text { Name of the learning } \\
\text { situation (and label) }\end{array}$ & $\begin{array}{l}\text { Design Team } \\
\text { Members }\end{array}$ & Profile of students & $\begin{array}{l}\text { No. of } \\
\text { students }\end{array}$ & $\begin{array}{l}\text { Dates of } \\
\text { enactment }\end{array}$ \\
\hline HE & $\begin{array}{l}\text { Programme for } \\
\text { Healthcare Education } \\
\text { [HE-Nursing] }\end{array}$ & 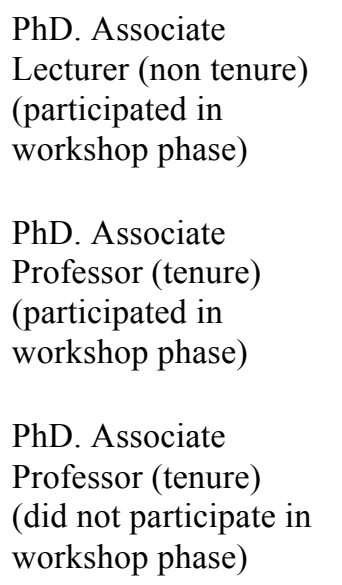 & $\begin{array}{l}\text { Degree in Nursing, } \\
\text { 3rd year (out of } \\
\text { four). University of } \\
\text { Valladolid, Spain }\end{array}$ & 128 & $\begin{array}{l}18 / 20 \\
\text { November } \\
2014 \\
\text { ( } 2 \text { two-hour } \\
\text { face-to-face } \\
\text { sessions) }\end{array}$ \\
\hline HE & $\begin{array}{l}\text { Radiodetermination } \\
\text { [HE-Telecom] }\end{array}$ & $\begin{array}{l}\text { PhD. Associate } \\
\text { Professor (tenure) } \\
\text { (participated in } \\
\text { workshop phase) } \\
\text { PhD. Associate } \\
\text { Professor (tenure) } \\
\text { (did not participate in } \\
\text { workshop phase) }\end{array}$ & $\begin{array}{l}\text { Degree in Telecom } \\
\text { Engineering - } \\
\text { Communication } \\
\text { Systems, 4th year } \\
\text { (out of four). } \\
\text { University of } \\
\text { Valladolid, Spain }\end{array}$ & 13 & $\begin{array}{l}10-17 \\
\text { December } \\
2014 \text { and } 7 \\
\text { January } 2015 \\
\text { ( } 3 \text { two-hour } \\
\text { face-to-face } \\
\text { sessions) }\end{array}$ \\
\hline HE & $\begin{array}{l}\text { Land Planning } \\
\text { [HE-Geo] }\end{array}$ & $\begin{array}{l}\mathrm{PhD} \text {. Associate } \\
\text { Professor (tenure) } \\
\text { (participated in } \\
\text { workshop phase) }\end{array}$ & $\begin{array}{l}\text { Degree on } \\
\text { Geography and } \\
\text { Land Planning, 3rd } \\
\text { year (out of four). } \\
\text { University of } \\
\text { Valladolid, Spain }\end{array}$ & 12 & $\begin{array}{l}\text { From } 16 \\
\text { October } \\
2014 \text { to } 15 \\
\text { January } 2015 \\
\text { (11 two-hour } \\
\text { face-to-face } \\
\text { sessions) }\end{array}$ \\
\hline $\mathrm{AE}$ & $\begin{array}{l}\text { A trip to Dublin } \\
\text { [AE-English] }\end{array}$ & $\begin{array}{l}\text { University Degree. } \\
\text { Teacher of the } \\
\text { Education and Culture } \\
\text { Unit, Adult Education, } \\
\text { Valladolid Province } \\
\text { (participated in the } \\
\text { workshop phase) }\end{array}$ & $\begin{array}{l}\text { Middle-aged } \\
\text { women of rural } \\
\text { area attending an } \\
\text { English course. } \\
\text { Valladolid } \\
\text { Province (Spain) }\end{array}$ & 9 & $\begin{array}{l}\text { From } 14 \\
\text { January } 2015 \\
\text { to } 27 \text { February } \\
2015 \text { ( } 5 \text { two- } \\
\text { hour face-to- } \\
\text { face sessions) }\end{array}$ \\
\hline
\end{tabular}




\begin{tabular}{|c|c|c|c|c|c|}
\hline $\mathrm{AE}$ & $\begin{array}{l}\text { Pros and cons of use of } \\
\text { ICT } \\
\text { [AE-Ict] }\end{array}$ & $\begin{array}{l}\text { University Degree } \\
\text { (Law). Teacher of the } \\
\text { Education and Culture } \\
\text { Unit, Adult Education, } \\
\text { Valladolid Province } \\
\text { (participated in the } \\
\text { workshop phase) }\end{array}$ & $\begin{array}{l}\text { Middle-aged men } \\
\text { and women of rural } \\
\text { area attending an } \\
\text { initial course on } \\
\text { ICT. Valladolid } \\
\text { Province (Spain) }\end{array}$ & 14 & $\begin{array}{l}\text { From } 19 \\
\text { January } 2015 \\
\text { to } 19 \text { February } \\
2015 \text { (4 two- } \\
\text { hour face-to- } \\
\text { face sessions) }\end{array}$ \\
\hline
\end{tabular}

The follow-up phase was facilitated by the same two researchers that were in charge of the workshop phase. Following the model presented in section 2.2, a number of regular face-to-face meetings took place among the two facilitators and the design teams for monitoring the design process and for helping the design teams overcome emerging pedagogical and technological issues. Communication among the facilitators and the design teams also happened asynchronously by means of email messages and ILDE community features (mostly feedback comments posted by the facilitators about the design artefacts created by the design teams in the ILDE). The follow-up phase finished with the enactment of the five designed CL situations, with actual students, during the end of 2014 and the beginning of 2015. All the implemented learning designs made use of the Moodle VLE, as well as of web 2.0 tools provided by third parties (mostly Google Drive applications: Google Documents, Google Spreadsheets, and Google Presentations).

\subsection{Method}

The research design of our study follows a concurrent embedded mixed-methods strategy (Creswell, 2009). According to such strategy, qualitative and quantitative data are collected simultaneously but, in this case, qualitative data is predominant and used for identifying general trends. On the other hand, quantitative data is considered within the study as of secondary importance and is mostly used to confirm/reject the identified trends as well as to enrich the description of the informants. This concurrent embedded strategy is generally appropriate when different groups or levels of informants are studied (Creswell, 2009). That is the case of the present study where the informants are not only the trained teachers that are studied both quantitatively (mostly during the workshop phase) and qualitatively (mostly during the follow-up phase), but also the learners involved in the enactment of the designs resulting from the follow-up phase, that are studied quantitatively.

The study uses a variety of data gathering techniques that are summarized in Table 2 . It is important to underline that the data coming from the members of the design teams are treated in an aggregated fashion, since individual opinions within each team tend to highly agree. Only some specific data excerpts refer to opinions or answers of the different members of the design teams, mostly to reflect interesting dialogues during interviews.

Table 2. Data gathering techniques and labels used to quote them throughout the text.

\begin{tabular}{|l|l|l}
$\begin{array}{l}\text { Collection of } \\
\text { teachers' } \\
\text { generated }\end{array}$ & $\begin{array}{l}\text { Collection of a diverse set of electronic artefacts generated by the teachers } \\
\text { participating in the study. Such collection includes: } \\
\bullet \text { During the workshop phase of the TPD: learning designs created with ILDE }\end{array}$ \\
\hline
\end{tabular}




\begin{tabular}{|c|c|}
\hline artefacts & $\begin{array}{l}\text { tools, posts in ILDE forums. Employed for registering the use of learning design } \\
\text { tools and the interactions among workshops participants in the involved } \\
\text { educational contexts (AE, HE) } \\
\text { [Art-HE-WS] [Art-AE-WS] } \\
\text { - During the follow-up phase of the TPD: emails with facilitators, posts in ILDE } \\
\text { forums. Used for registering emerging problems faced by the design teams } \\
\text { (usability of the ILDE, pedagogical doubts, ...) that required the help from } \\
\text { facilitators } \\
\text { [Mail-HE-Nursing][Mail-HE-Telecom][Mail-HE-Geo] } \\
\text { [Mail-AE-English][Mail-AE-Ict] } \\
\text { - During the follow-up phase of the TPD: learning design artefacts created with } \\
\text { ILDE tools along the three phases of the learning design full-lifecycle process. } \\
\text { Used for registering the use of the ILDE tools, as well as for assessing the } \\
\text { complexity and maturity of the learning designs created by the design teams. } \\
\text { [Art-HE-Nursing][Art-HE-Telecom][Art-HE-Geo] } \\
\text { [Art-AE-English][Art-AE-Ict] }\end{array}$ \\
\hline Observations & $\begin{array}{l}\text { Audio/Video recordings, pictures and observation notes collected: } \\
\text { - During the face-to-face sessions of the workshop phase of the TPD } \\
\text { [Obs-HE-WS] [Obs-AE-WS] } \\
\text { - During the face-to-face meetings of the members of the design teams with the } \\
\text { facilitators of the follow-up phase. } \\
{[\text { Obs-HE-Nursing][Obs-HE-Telecom][Obs-HE-Geo] }} \\
{[O b s-A E-E n g l i s h][O b s-A E-I c t]} \\
\text { Both information sources were used for registering emerging problems during the } \\
\text { workshops, and for registering opinions of the members of the design teams, as } \\
\text { well as the challenges (ILDE usability, pedagogical issues) they need to face during } \\
\text { the follow-up phase. }\end{array}$ \\
\hline Interviews & $\begin{array}{l}\text { Semi-structured, face-to-face conversations with the members of the design teams } \\
\text { at the end of the TPD process. They were carried out (and transcribed) by two of } \\
\text { the researchers (that were also the facilitators of the follow-up phase). One of those } \\
\text { researchers translated and transcribed the recorded interviews. Used for gathering } \\
\text { the overall opinions of the teachers about the TPD process: its format, the use of the } \\
\text { ILDE, future adoption, changes in perceptions after the follow-up phase, } \\
\text { perceptions about the affordability of the full-lifecycle learning design process, etc. } \\
\text { [Int-HE-Nursing][Int-HE-Telecom][Int-HE-Geo] } \\
\text { [Int-AE-English][Int-AE-Ict] }\end{array}$ \\
\hline Reflective Diary & $\begin{array}{l}\text { Written account by the members of the design teams of their experience during the } \\
\text { follow-up phase. All members of the design teams were asked to maintain this } \\
\text { diary, indicating the time they devoted to the learning design process, the problems } \\
\text { and doubts they faced, as well as their attitude (and how it changed) towards } \\
\text { learning design in general and the use of the ILDE in particular. No specific format } \\
\text { was suggested for the diary. } \\
\text { [Diary-HE-Nursing][Diary-HE-Telecom][Diary-HE-Geo] } \\
\text { [Diary-AE-English][Diary-AE-Ict] }\end{array}$ \\
\hline Questionnaires & $\begin{array}{l}\text { Set of open-ended and closed items used to: } \\
\text { - Gather data about the profiles and expectations of the teachers participating in }\end{array}$ \\
\hline
\end{tabular}




\begin{tabular}{|l|l|}
\hline the workshop phase \\
[QuestPre-HE-WS] [QuestPre-AE-WS] \\
(same questionnaire delivered to the participants in both workshops) \\
- Collect the opinion of the teachers participating in the workshop phase after the \\
workshop finished. \\
[QuestPost-HE-WS] [QuestPost-AE-WS] \\
(same questionnaire delivered to the participants in both workshops) \\
Collect the opinion of the students that took part in the enactment of the learning \\
designs created by the design teams during the follow-up phase. \\
[QuestStu-HE-Nursing][QuestStu-HE-Telecom][QuestStu-HE-Geo] \\
[QuestStu-AE-English][QuestStu-AE-Ict] \\
(same questionnaire delivered to the students participating in the enactments of \\
the five design teams)
\end{tabular}

The analysis of the data gathered during the study is guided by a data condensation process (Miles, Huberman, \& Saldaña, 2013) depicted in Figure 5. According to the condensation process, the main issue of the study (How does the ILDE contribute to the TPD program aimed at training teachers as designers of collaborative learning situations supported by ICT?) is illuminated through three more specific topics:

- The first topic (Topic T1) explores how the participants perceived the ILDE features that allegedly overcome two key deficiencies of current LD tooling, mentioned in the introduction: the support to full-lifecycle LD processes (subtopic T1a) and the support of teacher-designer community building (subtopic T1b). The other deficiency mentioned in the introduction, the lack of flexibility in LD tooling, is not explicitly explored in the study, since the participants (nonexperts in LD) were not allowed to decide which ILDE tools to use during their training. However, findings about flexibility do emerge from the exploration of this topic, as discussed in section 3.4 .

- Topic T2 tries to understand whether the combination of the proposed TPD model and the ILDE support implies an effort that is regarded as affordable by the participating teachers when compared with the benefits they perceive.

- Finally, Topic T3 is aimed at exploring the attitude of the participating teachers towards LD and its eventual adoption after completing the TPD program.

All those topics are explored by means of several informative questions (IQ, see Figure 5) that are nurtured by the analysis and triangulation of the data gathered using the techniques described in Table 2 .

Figure 6 depicts the flow of data gathering and analysis techniques (see labels defined in Table 2) employed throughout the study. Data were collected during the workshop and follow-up phases (including the enactment with students of the learning situations created by the design teams), and after the completion of the whole TPD program. Data (Table 2) are analysed using the elements of the data condensation diagram of Figure 5 as the initial set of codes. Coding is carried out by a single coder, although the codes themselves are discussed and agreed by the whole research team, as suggested by (Saldaña, 2015) for the coding solo strategy. Only the closed items of the questionnaires are treated quantitatively, using descriptive statistics, so as to confirm (or not) the findings from the qualitative analysis, and also to enrich the description of the teachers participating in the study. In order to contribute to the quality and credibility of the study, several steps are taken including (Guba, 1981): triangulation of 
techniques and data sources (see section 3.3), long permanence in the field (up to 6 months) and persistent observation by two of the authors (in their role as workshop instructors and facilitators during the followup phase), peer-debriefing between the two researchers that carried out the study and the rest of the members of the research team (including the discussion and agreement of the data condensation schema), as well as collection of thick descriptions of the context of the study.

(Research Question): what are the main features of the interplay between LD tooling and TPD programs aimed at training teachers as designers?

(Issue 11): How does the ILDE contribute to the TPD program aimed at training teachers as designers of collaborative

learning situations supported by ICT?

(Topic T1): Do ILDE features help teachers achieve their collaborative learning innovations during the TPD program?

(Subtopic T1a) Full-lifecycle support

Pedagogical support during the workshop and follow-up phase

IQ1.1. Do participating teachers find CL patterns useful for the design of their TEL innovations?

IQ1.2. Are participating teachers capable of adapting CL patterns to their TEL innovations?

Technological support during the workshop and follow-up phase

IQ1.3. Are the participating teachers able to follow and complete the full-lifecycle design process using the ILDE?

IQ1.4. Do the participating teachers follow and complete the full-lifecycle design process in order to redesign/adapt?

IQ1.5. Do the participating teachers perceive that the full-lifecycle design process, supported by the ILDE, help them carry out their TEL innovations?

Final outcomes

IQ1.6. Are the participating teachers satisfied with the TEL implemented designs? Emerging difficulties

IQ1.7. Do the participating teachers overcome conceptual/technological issues of their envisioned TEL innovations during the follow-up phase?

(Subtopic T1b) Community-support

IQ1.8. Is the ILDE community-support perceived as useful by the participating teachers?

IQ1.9. Does the ILDE community-support allow facilitators to support participating teachers along the full-lifecycle design process?

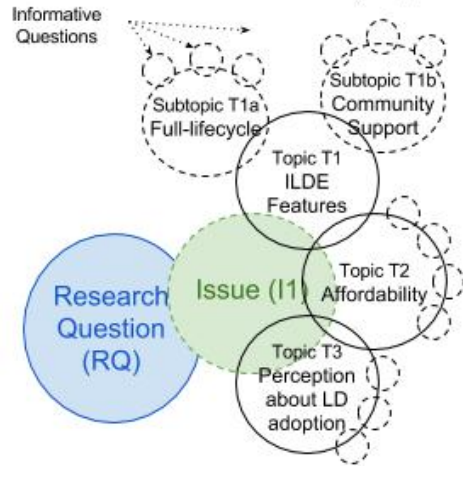

(Topic T2): Do the participating teachers perceive the ILDE-supported PD program as affordable?

IQ2.1. Is the ILDE-supported TPD program perceived as affordable by the participants?

IQ2.2. How much effort did it take to the participating teachers the "follow-up" phase?

(Topic T3): Do the participating teachers change their perception about potential adoption of LD practices after the ILDE-supported TPD program?

IQ3.1. Do the participating teachers change their perception about potential adoption of LD practices after the follow-up phase?

IQ3.2. Do the participating teachers intend to use the ILDE again after the ILDE-supported TPD program?

Figure 5. Data condensation diagram, inspired from Miles et al. (2013), showing the Research Question (RQ), Issue (I), topics and subtopics (T), and informative questions (IQ).

\subsection{Findings}

\subsubsection{Topic T1: ILDE features and TPD}

This topic explores how the full-lifecycle learning design process supported by ILDE, as well as its community features, were employed by the participating teachers during their training, and whether they perceived such features as helpful and/or easy to use. It is worth reminding (see section 2.2) that only a subset of the LD tools integrated in the ILDE were expected to be employed by the participating teachers: 
Persona and Dream templates during the conceptualization phase, WebCollage during the authoring phase, WebCollage and GLUE!-PS during the implementation. 


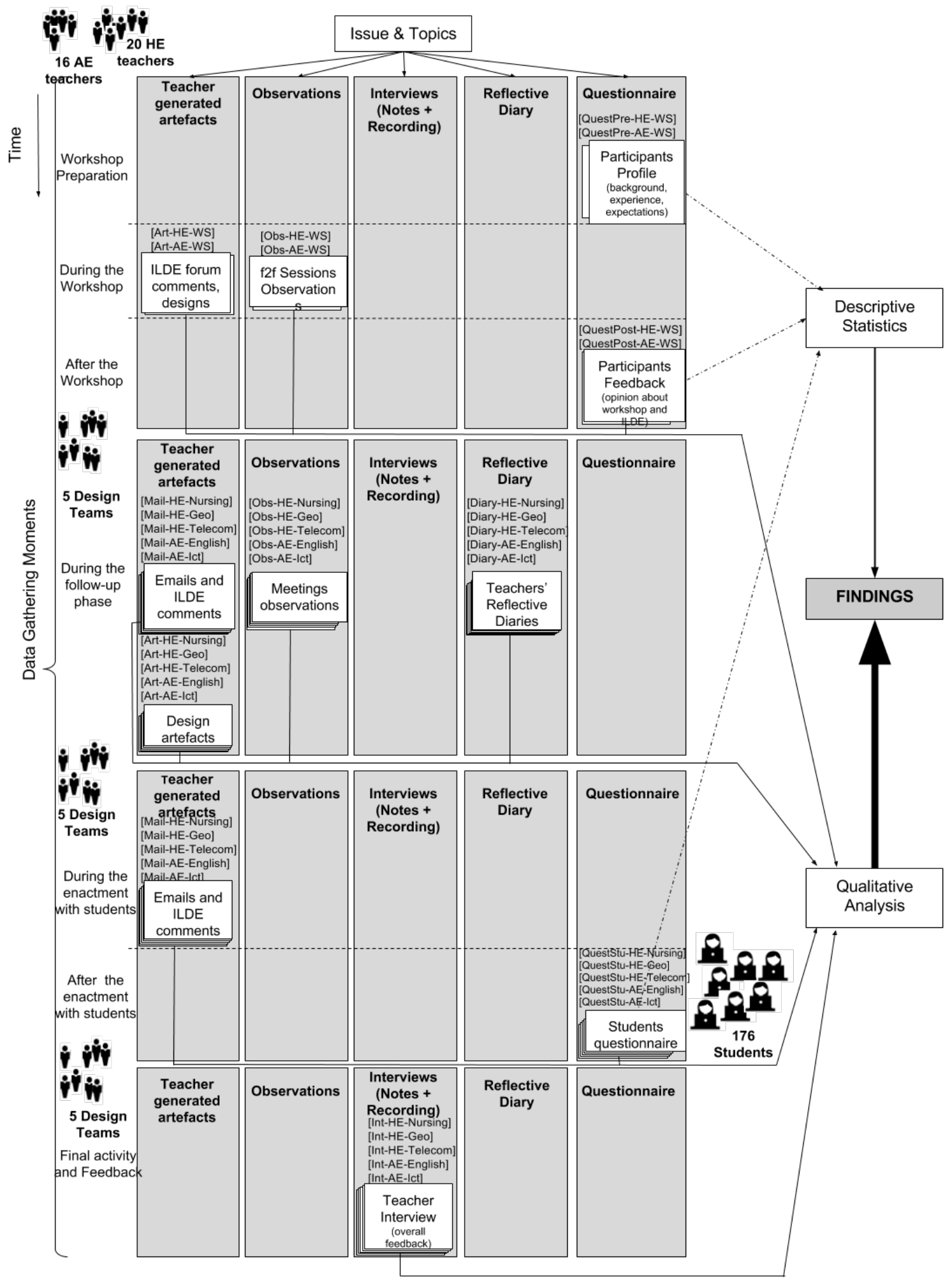

Figure 6. Data gathering moments and analysis techniques during the study. See Table 2 for an explanation of the labels. 


\section{Subtopic Tla: ILDE's full-lifecycle support}

Regarding Subtopic T1a (ILDE's full-lifecycle support) in relation with the workshop phase of the TPD program (see Table A.2 in Appendix), only 6 (out of 16) participants in the AE workshop were able to complete the LD full-lifecycle, as supported by the ILDE, using the sample learning situation provided by the facilitators (Finding F1a-1, Table A.2). The lack of time seems to be the reason why 10 participants did not complete the LD full-lifecycle (Finding F1a-2, Table A.2) which suggests that a duration of 4 hours is not enough for the workshop phase of the TPD program. In contrast, 18 (out of 20) participants in the HE workshop did complete the ILDE-supported LD full-lifecycle applying it to a learning situation of their own teaching context (Finding F1a-3, Table A.2). In fact, the participants in the HE workshop considered its duration (12.5 hours) as rather adequate, although a longer workshop format would be advisable (F1a-4, Table A.2). The complexity of the LD terminology introduced by the ILDE, as well as the number of different tools and phases involved in the ILDE-based LD process, were pointed out by the participants in the HE workshops as aspects to be improved (F1a-5, Table A.2). Interestingly, most of the designs that the participants of the HE workshop envisioned for situations of their own practice (16 out of 18) were based on the pyramid CL pattern (F1a-6, Table A.2), which happened to be the same that was illustrated by the sample learning situation provided by the facilitators of the workshop. Actually, the participants in the HE workshop considered that their designs were not too original or complex, although they valued those very same designs as rather complete and reusable (F1a-7, Table A.2).

Regarding the follow-up phase, all the design teams were able to complete the full-lifecycle LD process supported by the ILDE, implementing and enacting their designs in an authentic context with students (F1a-8, Table A.3 in the Appendix). All the enacted designs were based on one or several CL patterns (F1a-9 Table A.3), and all the design teams assessed their designs as highly or very highly complete, original and reusable (F1a-10, Table A.3). However, the assessment of the level of complexity was less homogenous, and seems to be correlated with the number and/or type of CL pattern employed in the designs. For instance, the [HE-Telecom] design team assessed its design as the least complex (it is actually based on a single two-level pyramid), while the [AE-Ict] team employed two nested pyramids, which happened to be more difficult to handle during the design (as expected). Nevertheless, all design teams appreciated the usefulness of the CL patterns to better organize the activities of the students as well as to better promote collaborative interactions (F1a-11, Table A.3).

In spite of the apparent success in applying the CL patterns to their teaching innovations, it is important to underline that, even though all the patterns provided by the ILDE were explained and documented during the workshop phase, most of the design teams needed the advice and support of the facilitators during the follow-up phase to understand how to customize the patterns to their teaching context (F1a-12, Table A.3). Similarly, and although all design teams considered that the support of the ILDE along the design process was very helpful (F1a-13, Table A.3), its learning curve was considered very steep at the beginning of the follow-up phase, even after having used the ILDE during the workshop phase (F1a-14, Table A.3). Therefore, the follow-up phase was crucial to help the design teams overcome the usability and terminology issues that emerged during their use of the ILDE (F1a-15, Table A.3). In any case, it is important to underline that all the teachers of the design teams considered that their designs were 
beneficial for the students that participated in the enactments, improving their achievements and/or facilitating collaborative tasks (F1a-16, Table A.3).

The teachers of the design teams also perceived that their students were able to follow the sequence of designed activities and that they were satisfied with the enacted designs (F1a-17, Table A.3), a perception confirmed by the feedback provided by the students themselves (see Table A.4 in the Appendix). Additionally, the teachers did not detect significant problems with the technological support, automatically set up by the ILDE, during the enactment of the implemented designs with the students (F1a-18, Table A.3). Only in the case of the [AE-English] design it took students some more effort to understand the CL technique employed by the teachers (F1a-19, Table A.3).

All in all, the five design teams considered that they had been able to put into practice what they had learnt during the workshop phase (F1a-20, Table A.3), and that following the full-lifecycle design process, as supported by the ILDE, helped them reflect on the learning situation, thus obtaining better designs (F1a-21, Table A.3).

\section{Subtopic T1b: ILDE's community support}

Regarding Subtopic T1b (ILDE's community support) participants in the AE workshop did not have time to explore the sharing and commenting features of ILDE (only one participant provided feedback about these features in [QuestPost-AE-WS]). In the case of the HE workshop, the data from [QuestPost-HEWS] indicates that sharing and duplicating own designs, as well as viewing and commenting others' designs, were the ILDE features most frequently used by participants. Such features were apparently perceived as useful and easy to use (see Table A.5 in the Appendix). The remaining community features (creating groups of ILDE users, exchanging messages among ILDE users, editing the design of other participants, viewing duplicated designs) were only scarcely used by two of the participants. Indeed, these results were somehow expected since those community features were not explicitly showcased by the facilitators during the workshop phase, and because most of the team discussions happened face to face, when only one member of the team carried out the actual editing of the designs in the ILDE.

Regarding the follow-up phase, data suggests that all the teachers in the design teams also considered that the features of reusing or sharing designs with other teachers or with the facilitators, as supported by the ILDE, are useful and easy to use (F1b-1, Table A.6 in the Appendix). However, the use of such features was limited to the sharing of the designs with the facilitators and, in a few cases, with other teachers (F1b2, Table A.6). Additionally, the facilitators reviewed the shared designs and provided feedback face-toface during the meetings or via email. Consequently, the commenting feature of the ILDE was also scarcely used by both the design teams and the facilitators.

\subsubsection{Topic T2: Affordability}

This topic explores the implications of introducing the ILDE support in the TPD program (described in section 2.2) in terms of the effort required from the participants. Actually, findings from Topic T1a (see section 3.3.1) suggested that the ILDE had a somewhat steep learning curve. Therefore, it is important to understand whether the additional effort derived from learning how to use the ILDE, as well as from 
following its underlying full-lifecycle learning design process, outweighed the benefits of the TPD program as perceived by the participants.

Interestingly, the participants in the AE and HE workshops were asked ([QuestPre-AE-WS][QuestPreHE-WS]) about how much time did they think it would be reasonable for implementing a learning scenario similar to the one provided as example (a CL pyramid of three levels that made use of Moodle and Google Drive tools). The range of answers spanned from 1 to 30 hours, without a clear correlation neither with the attitude towards CL, nor with the level of expertise in CL and/or the familiarity with educational technology.

However, data from the follow-up phase indicates that all the teachers from the design teams considered that the effort required to complete the TPD program (including both the workshop and follow-up phases) was rather high, although they also believed that the obtained results were worth it (F2-1, Table A.7 in the Appendix). Table A.8 (in the Appendix) provides some data that can help get a clearer idea of the effort devoted by the design teams to complete the follow-up phase of the ILDE-supported TPD program. Such effort measurements do not seem to be correlated to the educational level (AE vs. HE) nor to the complexity of the designs of the design teams. In any case, the teachers from the design teams expected the workload to decrease in future uses of the ILDE full-lifecycle learning design process (F2-2, Table A.7). It is worth underlining that the effort devoted by the teacher [HE-Geo] seems to be much higher than in the case of the other design teams. A plausible interpretation to this data can be linked to the personality of the teacher, who appeared to pay a lot of attention to the details (F2-3, Table A.7). This link between devoted effort and teacher personality traits (like, e.g., perfectionism) needs to be studied in future work.

Another interesting finding is that some of the design teams explicitly stated that the use of the ILDE saved them time in specific tasks when setting up the technological platform for the enactment (i.e., the implementation phase of the ILDE full-lifecycle learning design process) (F2-4, Table A.7).

\subsubsection{Topic T3: Perception about adoption}

This topic explores the attitude towards LD in general, and towards the use of ILDE in particular, of the participants that completed the TPD program. Data gathered from the follow-up phase suggests that all the participants in the design teams had the intention to keep on using the ILDE in their future teaching innovations (F3-1, Table A.9 in the Appendix). Additionally, they considered that what they had learnt during the whole TPD program had impacted, or could impact their own practice. They also considered that the ILDE and the TPD program matched the needs of their institutions and work sector at large (both $\mathrm{AE}$ and $\mathrm{HE}$ ), thus enabling their eventual larger adoption, with some potential caveats in terms of TPD duration, existing negative attitudes towards innovation, and high effort required for completing the fulllifecycle LD process (F3-2, Table A.9). Again, several teachers emphasized how the ILDE-based TPD program helped them increase their level of reflection about their own practice (F3-3, Table A.9), which is one of the expected benefits of adopting LD practices.

\subsection{Discussion and lessons learnt}


The evidence gathered during this study constitutes a first attempt to achieve the research question addressed by this paper: what are the main features of the interplay between LD tooling and TPD programs aimed at training teachers as designers? A first interpretation of the findings suggests that, as expected, using purpose-specific LD tooling in TPD programs implies an additional burden for the participants. Indeed, the workload increase associated with the introduction of the ILDE in the TPD program also explains why a too short workshop phase (e.g., the case of the 4-hour AE workshop) seems to be insufficient for achieving all the goals of the TPD in terms of both pedagogical and technological aspects. A longer workshop phase (e.g., the case of the 12.5-hour HE workshop) did allow participants to complete the ILDE full-lifecycle design process with a learning situation of their teaching context. However, most of the learning designs created by the participants of the HE workshop were based on the same CL pattern used in the sample learning situation provided by the facilitators of the workshop. This finding suggests that participants did not have enough time during the workshop phase to reflect on the pedagogical aspects of their designs. Therefore, and confirming some findings from other TPD program studies tackling the challenge of training of teachers as designers (Kali \& Ronen-Fuhrmann, 2011; Mor \& Mogilevsky, 2013), the follow-up phase of the TPD program gives the participants the opportunity to better reflect on their pedagogical designs and to make them explicit. As expected, the participants in the follow-up phase also acknowledged a high increase in the workload for preparing their teaching when compared to their previous practices. However, they also underlined that the obtained results far outweighed the required effort since, in the end, they could enact a non-trivial CL situation supported by a technological setting based on a combination of Moodle and a set of web 2.0 tools. Interestingly, and unlike related studies (e.g., Kali \& Ronen-Fuhrmann, 2011), the participants in the study had a marginal previous expertise in both the CL pedagogical approach and the educational use of the ICT, thus partially explaining their enthusiasm when assessing the outcomes of the TPD process. Since the technological setting was automatically configured by the ILDE, the participants could save time in technology-related, often repetitive and tedious tasks (e.g., configuring changing groups in Moodle, creating copies of web 2.0 tools for those groups and link them into Moodle, etc.) and focus more on reflecting about their pedagogical design, which was highly appreciated.

Also, the LD terminology and the need to use diverse ILDE tools along the LD cycle were pointed out by the participants in the study as some of the main additional hurdles that the ILDE brought to the TPD program. Interestingly, there seems to be a trade-off between the claim for higher flexibility in LD tooling in terms of diverse representations, design paths, underlying pedagogies, etc. (Bennett et al., 2015) and the need for a simpler, more homogenous view of the LD tools integrated by the ILDE, as suggested by the results of the study presented in this paper. The assumption underlying the ILDE's design was to foster flexibility by integrating a range of LD tools as wide as possible, thus covering a number of different design paths. However, such level of flexibility is useful for designers that know a priori the features and affordances of the available LD tools and the possibilities of their combined use, which was not the case of the participants in the study, non-experts in LD. This apparent need of supporting both guided and flexible design paths in LD tooling is aligned with the conclusions of previous research studies (Masterman \& Manton, 2011; Prieto et al., 2014). Therefore, adding a layer of guidance to help navigate the multiple flexible combinations of LD tooling that ILDE enables might be a convenient feature in TPD contexts similar to the one explored in the presented study. In any case, as also suggested by the findings of the study, the follow-up phase contributed to overcome terminology and usability issues regarding the ILDE tools and the underlying full-lifecycle design process. 
In addition to all the above mentioned encouraging results, the study also detected that the reaction of the students to the enacted teaching innovations was very positive. This aspect, which is not frequently explored in existing LD-related research works, can help explain why the teachers participating in the follow-up phase, after assessing the perception of their students, expressed their intention to use the ILDE again in the future. It can also explain why they considered that the ILDE, and the accompanying TPD program model, could play a role in their institutions at a larger scale. However, this same finding is not comparing the student learning benefits of the new designs with those of previous, non CL and LD-based learning situations. This limitation, shared with most of the research on LD, presents an interesting avenue of future research, both by researchers and by teachers themselves (see, e.g., the teacher inquiry into student learning approach proposed by Emin-Martínez et al., 2014).

On the negative side, the study pointed out the limited use of ILDE's community features among participants. Such features indeed helped the interaction among participants and facilitators, but it is apparent that the participants did not feel the need to reuse other colleagues' designs, nor follow their progress along the TPD program. The study does not provide a clear explanation to this lack of interdesign team collaboration, but since collaboration among teams was not explicitly fostered by specific planned activities of the TPD model, it is reasonable not to expect it to happen spontaneously (Persico \& Pozzi, 2013). Furthermore, the permanent supervision by the facilitators during the follow-up phase (answering doubts, providing advice, etc.) would be an additional plausible cause.

The study has two main limitations. First of all, the TPD program was not mandatory, which suggests a bias in the profiles of the participating teachers. As pointed out by other studies (see, e.g., Prieto et al. 2014), militant teachers are more likely to show positive attitudes towards the adoption of LD tools and practices. Thus, understanding the impact of the ILDE-supported TPD program in the case of compulsory training contexts, where negative attitudes to ICT and CL might be significant barriers for adoption, is an open issue that requires further research, as also pointed out by related works (Mor \& Mogilevsky, 2013). Interestingly, some of the teachers of the design teams also raised this very same issue when reflecting about possible future adoption of the ILDE and the training approach in their institutions.

A second limitation of the study is that it does not provide insights about how the members of the design teams collaborated during the follow-up phase. Investigating the dynamics of co-design talks (as in Boschman, McKenney, \& Voogt, 2015) could help better understand the way TPACK develops during the ILDE-support TPD program. However, the design of the study treated each design team as a unique informant, not digging sufficiently into the finer-grained, intra-team interactions.

\section{$4 \quad$ Conclusions and future work}

The results of the presented study suggest that LD tooling capable of supporting a complete design process (from the initial conceptualization of the design to the setting up of the technological support for the learning activities to be carried out by the students), can be highly beneficial in TPD actions aimed at fostering the role of teachers as designers. According to the evidence from our study, the full-lifecycle LD support provided by the ILDE was highly appreciated by the participating teachers, in spite of its steep learning curve and the effort its usage requires (which had to be accommodated by the follow-up phase of 
the implemented TPD model). Indeed, the teachers that participated in the study showed a positive attitude towards an eventual adoption of LD practices and tools, an attitude that was also supported by the feedback gathered from the students who took part in the enactment of the designed innovations. This exploration of the interplay between LD tooling and TPD, scarce so far in the LD field, is a promising step towards the ultimate goal of understanding how to transfer research results from the LD field to actual teaching practice.

The TPD model explored in our study was focused on CL and ICT integration. However, this research provides findings about the use of ILDE features for TPD that go beyond CL approaches. This opens the door to applicability and future studies focused on other learning methods. Additionally, several lines for future work derive from limitations of the presented study. First of all, the trade-off between flexibility (posited as necessary by Bennett et al., 2017) and stronger guidance when scaffolding LD processes (as suggested by the results from the study presented in this paper) is still an open issue that can greatly influence design decisions when developing LD tooling. Secondly, this study does not address potential scalability issues of the personalized support provided by the facilitators during the follow-up phase. This issue suggests the need to investigate other TPD formats based on, e.g., Massive Open Online Courses (MOOCs). Recent research efforts are actually exploring the role that the ILDE might play in such largescale TPD contexts (see, e.g., Garreta-Domingo, Hernández-Leo, Mor \& Sloep, 2015). Last but not least, additional research is needed to achieve a better understanding of how the development of TPACK is related to the collaboration dynamics among teachers participating in TPD when co-designing their learning situations, as well as the role of the community features in LD tooling (see some recent efforts around the ILDE in, e.g., Michos \& Hernández-Leo, 2016).

Investigating the dynamics of co-design talks (as in Boschman, McKenney, \& Voogt, 2015) could help better understand the way TPACK develops during the ILDE-support TPD program. However, the design of the study treated each design team as a unique informant, not digging sufficiently into the finergrained, intra-team interactions.

Our study shows the benefits of an environment that supports the whole LD lifecycle. However, promoting a participatory culture of LD might be even more difficult, since there may be barriers to this generated by how educational institutions work. In any case, the shift towards a culture of teachers as designers is a considerable paradigm change which cannot be easily (or hurriedly) attained. One thing we can be sure of, is that TPD is key to this change, and that TPD must intertwine with practice, if it must be effective. We strongly believe that LD tooling that both aligns with TPD and scaffolds the full lifecycle of design practice will be crucial to achieve this shift.

\section{References}

Agostinho, S., Bennett, S., Lockyer, L., Jones, J., \& Harper, B. (2013). Learning designs as a stimulus and support for teachers' design practices. In H. Beetham \& R. Sharpe (Eds.), Rethinking pedagogy for a digital age (pp. 119-132). New York, NY: Routledge. https://doi.org/10.4324/9780203961681 
Alario-Hoyos, C., Bote-Lorenzo, M. L., Gómez-Sánchez, E., Asensio-Pérez, J. I., Vega-Gorgojo, G., \& Ruiz-Calleja, A. (2013). GLUE!: An architecture for the integration of external tools in Virtual Learning Environments. Computers \& Education, 60(1), 122-137. https://doi.org/10.1016/j.compedu.2012.08.010

Bennett, S., Agostinho, S., \& Lockyer, L. (2015). Technology tools to support learning design: Implications derived from an investigation of university teachers' design practices. Computers \& Education, 81, 211-220. https://doi.org/10.1016/j.compedu.2014.10.016

Bennett, S., Agostinho, S., \& Lockyer, L. (2017). The process of designing for learning: understanding university teachers' design work. Educational Technology Research and Development, 65(1), 125-145. https://doi.org/10.1007/s11423-016-9469-y

Bjælde, O. E., Caspersen, M. E., Godsk, M., Hougaard, R. F., \& Lindberg, A. B. (2015). Learning design for science teacher training and educational development. In Proceedings of the Australasian Society for Computers in Learning and Tertiary Education (ASCILITE 2015), 21-30.

Boschman, F., McKenney, S., \& Voogt, J. (2015). Exploring teachers' use of TPACK in design talk: The collaborative design of technology-rich early literacy activities. Computers \& Education, 82, 250-262. https://doi.org/10.1016/j.compedu.2014.11.010

Branch, R. M. (2009). Instructional design: The ADDIE approach. Springer Science \& Business Media. https://doi.org/10.1007/978-0-387-09506-6

Celik, D., \& Magoulas, G. D. (2016). A review, timeline, and categorization of learning design tools. In Proceedings of the 15th International Conference on Web-Based Learning (ICWL 2016), 3-13. https://doi.org/10.1007/978-3-319-47440-3

Chacón-Pérez, J., Hernández-Leo, D., Mor, Y., \& Asensio-Pérez, J. I. (2016). User-centered design: supporting learning designs' versioning in a community platform. In B. Gros, Kinshuk, \& M. Maina (Eds.), The Future of Ubiquitous Learning (pp. 171-196). Springer Berlin Heidelberg. https://doi.org/10.1007/978-3-662-47724-3

Conole, G. (2015). Theoretical underpinnings of learning design. In J. Dalziel (Ed.), Learning Design: Conceptualizing a Framework for Teaching and Learning Online (pp. 42-62). New York, NY: Routledge.

Creswell, J. W. (2009). Research design: qualitative, quantitative, and mixed methods approaches. 3rd Edition. SAGE Publications.

Cross, S., Galley, R., Brasher, A., \& Weller, M. (2012). OULDI-JISC Project evaluation report: the impact of new curriculum design tools and approaches on institutional process and design cultures. Retrieved from http://oro.open.ac.uk/34140. Last accessed: January, 2017. 
Dalziel, J., Conole, G., Wills, S., Walker, S., Bennett, S., Dobozy, E., Cameron, L., Badilescu-Buga, E., \& Bower, M. (2013). The Larnaca declaration on learning design 2013. Retrieved from http://platform.europeanmoocs.eu/users/65/LarnacaDeclaration2013.pdf. Last accessed: January, 2017.

Delfino, M., \& Persico, D. (2007). Online or face-to-face? Experimenting with different techniques in teacher training. Journal of Computer Assisted Learning, 23(5), 351-365. https://doi.org/10.1111/j.1365$\underline{2729.2007 .00220 . x}$

Derntl, M., Neuman, S., \& Oberhuemer, P. (2011). Propelling standards-based sharing and reuse in instructional modeling communities: The open graphical learning modeler (OpenGLM). In Proceedings of the 11th IEEE International Conference on Advanced Learning Technologies (ICALT 2011), 431-435. https://doi.org/10.1109/ICALT.2011.135

Dimitriadis, Y., \& Goodyear, P. (2013). Forward-oriented design for learning: illustrating the approach. Research in Learning Technology, 21:20290. https://doi.org/10.3402/rlt.v21i0.20290

Dobozy, E. (2013). Learning design research: advancing pedagogies in the digital age. Educational Media International, 50(1), 63-76. https://doi.org/10.1080/09523987.2013.777181

Dobozy, E., \& Campbell, C. (2016). The complementary nature of learning design and TPACK. In Dalziel, J. (Ed.), Learning Design: Conceptualizing a Framework for Teaching and Learning Online (pp. 96-116). New York, NY: Routledge.

Emin-Martínez, V., Hansen, C., Rodríguez-Triana, M.J., Wasson, B., Mor, Y., Dascalu, M., Ferguson, R., \& Pernin, J.-P. (2014). Towards teacher-led design inquiry of learning. eLearning Papers, 36.

Ertmer, P. A., \& Ottenbreit-Leftwich, A. (2013). Removing obstacles to the pedagogical changes required by Jonassen's vision of authentic technology-enabled learning. Computers \& Education, 64, 175-182. https://doi.org/10.1016/j.compedu.2012.10.008

Garreta-Domingo, M., Hernández-Leo, D., Mor, Y., \& Sloep, P. (2015). Teachers' perceptions about the HANDSON MOOC: A learning design studio case. In Proceedings of the 10th European Conference on Technology Enhanced Learning (EC-TEL 2015), 420-427. https://doi.org/10.1007/978-3-319-24258-3 34

Goodyear, P., \& Dimitriadis, Y. (2013). In medias res: reframing design for learning. Research in Learning Technology, 21:19909. https://doi.org/10.3402/rlt.v21i0.19909

Goodyear, P. (2015). Teaching as design. HERDSA Review of Higher Education, 2, 27-50.

Guba, E. (1981). Criteria for assessing the trustworthiness of naturalistic inquiries. A Journal of Theory, Research, and Development on Educational Communication and Technology, 29, 75-91. https://doi.org/10.1007/BF02766777 
Hernández-Leo, D., Villasclaras-Fernández, E. D., Asensio-Pérez, J. I., Dimitriadis, Y., Jorrín-Abellán, I. M., Ruiz-Requies, I., \& Rubia-Avi, B. (2006). COLLAGE: A collaborative learning design editor based on patterns. Journal of Educational Technology and Society, 9(1), 58-71.

Hernández-Leo, D., Villasclaras-Fernández, E. D., Asensio-Pérez, J. I., \& Dimitriadis, Y. (2009). Generating CSCL scripts: From a conceptual model of pattern languages to the design of real scripts. In P. Goodyear \& S. Retalis (Eds.). (2009). E-learning Design Patterns and Pattern Languages (pp. 49-64). Sense Publishers.

Hernández-Leo, D., Romeo, L., Carralero, M. A., Chacón, J., Carrió, M., Moreno, P., \& Blat, J. (2011). LdShake: Learning design solutions sharing and co-edition. Computers \& Education, 57(4), 2249-2260. https://doi.org/10.1016/j.compedu.2011.06.016

Hernández-Leo, D., Asensio-Pérez, J. I., Derntl, M., Prieto, L. P., \& Chacón, J. (2014). ILDE: community environment for conceptualizing, authoring and deploying learning activities. In Proceedings of the 9th European Conference on Technology Enhanced Learning (EC-TEL 2014), 490-493. https://doi.org/10.1007/978-3-319-11200-8 48

IMS Global Learning Consortium. (2003). IMS learning design specification. Retrieved from https://www.imsglobal.org/learningdesign/index.html. Last accessed: January, 2017.

Kalantzis, M., \& Cope, B. (2010). The teacher as designer: Pedagogy in the new media age. E-learning and Digital Media, 7(3), 200-222. https://doi.org/10.2304/elea.2010.7.3.200

Kali, Y., \& Ronen-Fuhrmann, T. (2011). Teaching to design educational technologies. International Journal of Learning Technology, 6(1), 4-23. https://doi.org/10.1504/IJLT.2011.040147

Kali, Y., McKenney, S., \& Sagy, O. (2015). Teachers as designers of technology enhanced learning. Instructional science, 43(2), 173-179. https://doi.org/10.1007/s11251-014-9343-4

Katsamani, M., \& Retalis, S. (2011). Making learning designs in layers: The CADMOS approach. In Proceedings of the IADIS Multi Conference on Computer Science and Information Systems (pp. 305-312).

Koehler, M. J., Mishra, P., Kereluik, K., Shin, T. S., \& Graham, C. R. (2014). The technological pedagogical content knowledge framework. In J.M. Spector, M.D. Merrill, J. Elen, \& M.J. Bishop (Eds.), Handbook of research on educational communications and technology (pp. 101-111). New York, NY: Springer. https://doi.org/10.1007/978-1-4614-3185-5

Laurillard, D. (2012). Teaching as a design science. building pedagogical patterns for learning and technology. Routledge.

Maina, M., Craft, B., \& Mor, Y. (Eds.) (2015). The art \& science of Learning Design. Springer. https://doi.org/10.1007/978-94-6300-103-8 
Masterman, E., \& Manton, M. (2011). Teachers' perspectives on digital tools for pedagogic planning and design. Technology, Pedagogy and Education, 20(2), 227-246. https://doi.org/10.1080/1475939X.2011.588414

McKenney, S., Kali, Y., Markauskaite, L., \& Voogt, J. (2015). Teacher design knowledge for technology enhanced learning: an ecological framework for investigating assets and needs. Instructional Science, 43(2), 181-202. https://doi.org/10.1007/s11251-014-9337-2

Michos, K., \& Hernández-Leo, D. (2016). Understanding collective behavior of learning design communities. In Proceedings of the 11th European Conference on Technology Enhanced Learning (ECTEL 2016), 614-617. https://doi.org/10.1007/978-3-319-45153-4 75

Miles, M. B., Huberman, A. M., \& Saldaña, J. (2013). Qualitative data analysis: A methods sourcebook. SAGE Publications.

Mor, Y., Craft, B., \& Hernández-Leo, D. (2013). Editorial: The art and science of learning design. Research in Learning Technology, 21:22513. https://doi.org/10.3402/rlt.v21i0.22513

Mor, Y., \& Mogilevsky, O. (2013). The learning design studio: collaborative design inquiry as teachers' professional development. Research in Learning Technology, 21:22054. https://doi.org/10.3402/rlt.v21i0.22054

Murthy, S., Iyer, S., \& Warriem, J. (2015). ET4ET: a large-scale faculty professional development program on effective integration of educational technology. Educational Technology \& Society, 18(3), $16-28$.

Orlikowski, W.J., \& Baroudi, J.J. (1991). Studying information technology in organizations: Research approaches and assumptions. Information systems research, 2(1), 1-28. https://doi.org/10.1287/isre.2.1.1

Persico, D., \& Pozzi, F. (2013). The role of representations for the development of a participatory culture of Learning Design among educators. In Proceedings of the Learning \& Teaching with Media \& Technology Conference, (pp. 365-372).

Persico, D., Milligan, C., \& Littlejohn, A. (2015). The interplay between self-regulated professional learning and teachers' work-practice. Procedia-Social and Behavioral Sciences, 191:2481-2486. https://doi.org/10.1016/j.sbspro.2015.04.590

Prieto, L.P., Dimitriadis, Y., Craft, B., Derntl, M., Emin, V., Katsamani, M., Laurillard, D., Masterman, E., Retalis, S., \& Villasclaras-Fernández, E. (2013a). Learning design Rashomon II: exploring one lesson through multiple tools. Research in Learning Technology, 21:20057. https://doi.org/10.3402/rlt.v21i0.20057 
Prieto, L.P., Dimitriadis, Y., Asensio-Pérez, J.I., Jorrín-Abellán, I.M., \& Villagrá-Sobrino, S.L. (2013b). Fostering CSCL adoption: An approach to professional development focused on orchestration. In N. Rummel, M. Kapur, M. Nathan, \& S. Puntambekar (Eds.), Computer Supported Collaborative Learning 2013 (pp. 383-390). International Society of the Learning Sciences.

Prieto, L. P., Asensio-Pérez, J. I., Muñoz-Cristóbal, J. A., Dimitriadis, Y. A., Jorrín-Abellán, I. M., \& Gómez-Sánchez, E. (2013c). Enabling teachers to deploy CSCL designs across distributed learning environments. IEEE Transactions on Learning Technologies, 6(4), 324-336. https://doi.org/10.1109/TLT.2013.22

Prieto, L. P., Tchounikine, P., Asensio-Pérez, J. I., Sobreira, P., \& Dimitriadis, Y. (2014). Exploring teachers' perceptions on different CSCL script editing tools. Computers \& Education, 78, 383-396. https://doi.org/10.1016/j.compedu.2014.07.002

Pozzi, F., Ceregini, A., Dagnino, F., Ott, M., \& Tavella, M. (2015). Supporting the "whole learning design life-cycle" through the Pedagogical Planner, In Proceedings of the 1st D4Learning International Conference - Innovations in Digital Learning for Inclusion, 90-97.

Pozzi, F., Asensio-Pérez, J. I., \& Persico, D. (2016). The case for multiple representations in the learning design life cycle. In B. Gros, Kinshuk, \& M. Maina (Eds.), The Future of Ubiquitous Learning: Learning Designs for Emerging Pedagogies (pp. 171-196). Berlin Heidelberg: Springer. https://doi.org/10.1007/978-3-662-47724-3

Sagy, O., \& Kali, Y. (2014). Teachers as design-researchers of technology-enhanced learning. In Proceedings of the 9th CHAIS Conference for the Study of Innovation and Learning Technologies: Learning in the Technological Era, 88-93.

Saldaña, J. (2015). The coding manual for qualitative researchers. SAGE Publications.

Svihla, V., Reeve, R., Sagy, O., \& Kali, Y. (2015). A fingerprint pattern of supports for teachers' designing of technology-enhanced learning. Instructional Science, 43(2), 283-307. https://doi.org/10.1007/s11251-014-9342-5

Stake, R. E. (2010). Qualitative research: Studying how things work. Guilford Press.

Villasclaras-Fernández, E., Hernández-Leo, D., Asensio-Pérez, J.I., \& Dimitriadis, Y. (2013). Web Collage: An implementation of support for assessment design in CSCL macro-scripts. Computers \& Education, 67, 79-97. https://doi.org/10.1016/j.compedu.2013.03.002

Voogt, J., Westbroek, H., Handelzalts, A., Walraven, A., McKenney, S., Pieters, J., \& De Vries, B. (2011). Teacher learning in collaborative curriculum design. Teaching and Teacher Education, 27(8), 1235-1244. https://doi.org/10.1016/j.tate.2011.07.003 


\section{Appendix}

Table A.1. Overview of the attitude towards CL of the teachers participating in the workshop phase, as well as their level of usage of CL and the application of ICT in their teaching practice ([QuestPre-HEWS] [QuestPre-AE-WS] data sources, see subsection 3.2). 11 (out of 16 participants) AE teachers and 19 (out of 20 participants) HE teachers answered the questionnaires.

\begin{tabular}{|c|c|c|c|}
\hline & $\begin{array}{l}\text { General attitude towards } \\
\text { Collaborative Learning } \\
\text { (range 1= "I don't think it can } \\
\text { work" to 7= "I cannot } \\
\text { understand learning without } \\
\text { collaboration") }\end{array}$ & $\begin{array}{l}\text { How much do you use } \\
\text { Collaborative Learning in } \\
\text { your regular teaching? } \\
\text { (range } 1=\text { "Never" to } 7=\text { "In } \\
\text { my courses there are multiple } \\
\text { collaborative assignments } \\
\text { using different groupings and } \\
\text { combinations") }\end{array}$ & $\begin{array}{l}\text { How often do you use ICT } \\
\text { for supporting } \\
\text { Collaborative Learning? } \\
\text { (range 1= "Never" to } 7= \\
\text { "always, in every } \\
\text { collaborative activity") }\end{array}$ \\
\hline $\begin{array}{l}\text { Adult } \\
\text { Education } \\
\text { Teachers } \\
(\mathrm{N}=11)\end{array}$ & $\begin{array}{lllllll}5 & & & & & & \\
4 & & & & & & \\
3 & & & & & \\
2 & & & & & \\
1 & & & & & & \\
0 & 1 & 2 & 3 & 4 & 5 & 6\end{array}$ & $\begin{array}{lllllllll}4 & & & & & & & \\
3 & & & & & & & \\
2 & & & & & & & \\
1 & & & & & & & & \\
0 & & & & & & & & \\
0 & 1 & 2 & 3 & 4 & 5 & 6 & 7\end{array}$ & $\begin{array}{ll}6 & \\
5 & \\
4 & \\
3 & \\
2 & \\
1 & \\
0 & \\
& 1\end{array}$ \\
\hline $\begin{array}{l}\text { Higher } \\
\text { Education } \\
\text { Teachers } \\
(\mathrm{N}=19)\end{array}$ & 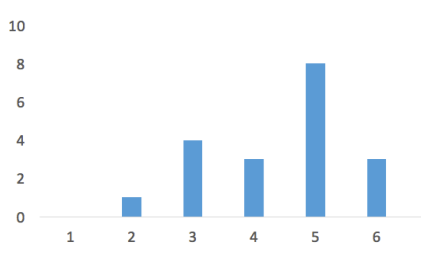 & $\begin{array}{lllllll}8 & & & & & & \\
6 & & & & & & \\
4 & & & & & & \\
4 & & & & & \\
2 & & & & & & \\
0 & 1 & 2 & 3 & 4 & 5 & 6\end{array}$ & $\begin{array}{lllll}8 & & & & \\
6 & & & & \\
4 \\
2 \\
0\end{array}$ \\
\hline
\end{tabular}

Table A.2. Selected excerpts of evidence supporting findings regarding Subtopic T1a (ILDE's fulllifecycle support) in relation with the workshop phase.

\begin{tabular}{|l|l|l|}
\hline Data source & Excerpts & $\begin{array}{l}\text { Supported } \\
\text { Findings }\end{array}$ \\
\hline [Art-AE-WS] & $\begin{array}{l}\text { Only 6 (out of 16) participants in the AE workshop completed the full LD lifecycle, } \\
\text { as supported by the ILDE, using the example provided by the facilitators as starting } \\
\text { point }\end{array}$ & F1a-1 \\
\hline [Obs-AE-WS] & $\begin{array}{l}\text { A "Lack of time for participants to implement a design created by them or, at least, } \\
\text { the sample scenario. Some participants encountered problems when implementing } \\
\text { the design of the sample scenario" } \\
\text { B "The participants pose some questions when there are doubts. My personal } \\
\text { perception, in general, is that so much information in such a short time might be } \\
\text { overwhelming, especially when there is not time for each participant to take his/her } \\
\text { time and follow the demo explanations with his/her laptop." }\end{array}$ & F1a- \\
\hline [QuestPost-AE-WS] & $\begin{array}{l}\text { To the question: "Rate the adequacy of the time schedule" (5 point Likert scale: } \\
\text { very low, low, neutral, high, very high) (N=8): low (2), neutral (3), high (3) }\end{array}$ & F1a-2 \\
\hline
\end{tabular}




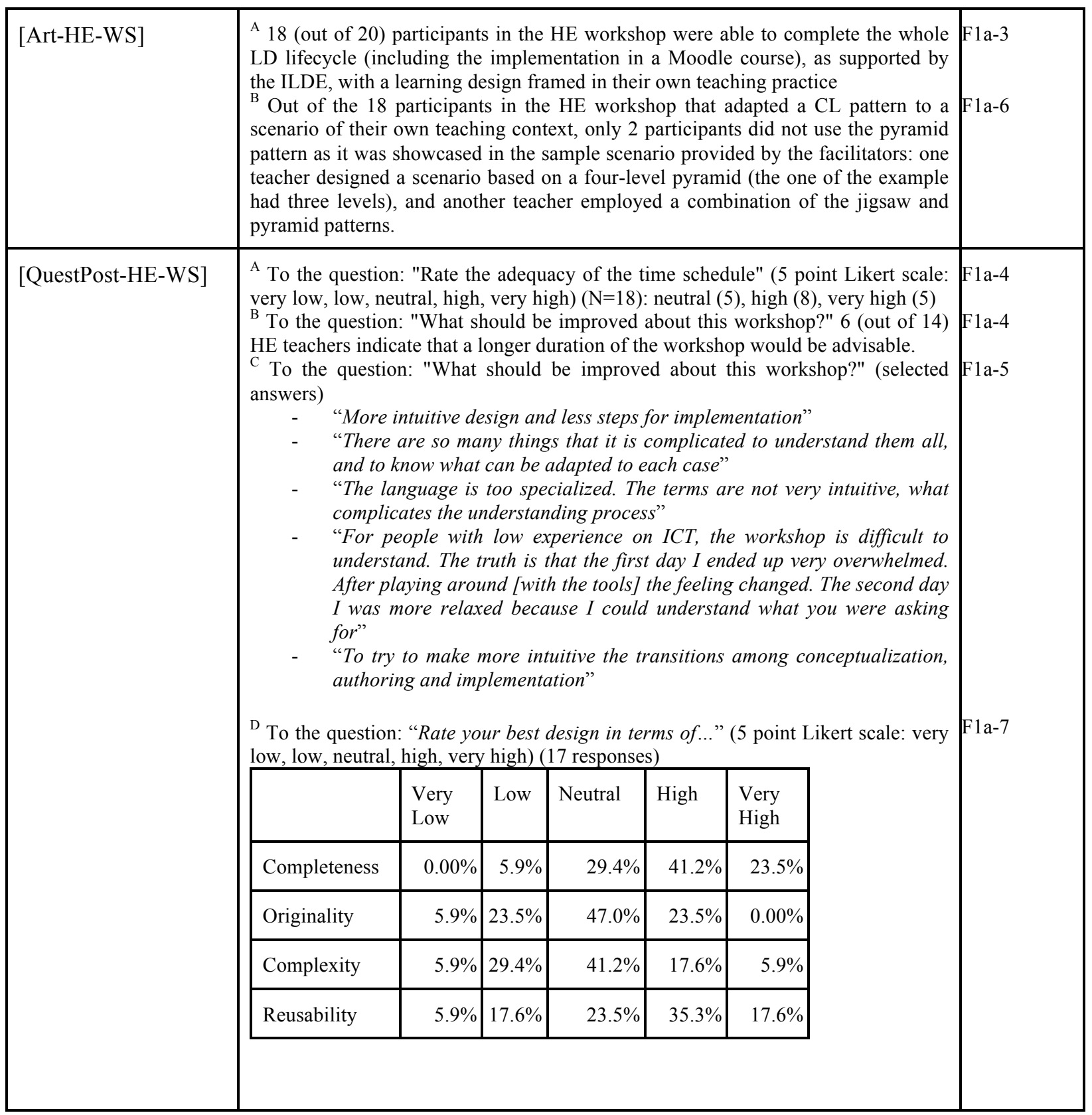

Table A.3. Selected excerpts of evidence supporting findings regarding Subtopic T1a (ILDE's fulllifecycle support) in relation with the follow-up phase.

\begin{tabular}{|l|l|l|}
\hline Data source & Excerpts & $\begin{array}{l}\text { Supported } \\
\text { Finding }\end{array}$ \\
\hline [Int-HE-Nursing] & $\begin{array}{l}\text { A Question: "How many designs were you able to enact with students"? Answer: } \\
\text { "One". } \\
\text { B Question: "Rate your design in terms of" (5 point Likert scale: very low, low, neutral, } \\
\text { high, very high): Completeness (4), Originality (4), Complexity (3), Reusability (5) } \\
\text { C "We had made a plan for all the practical work of the course. Then we realized that } \\
\text { we were going crazy: let's work only with the goals part, because if we had to do }\end{array}$ & $\begin{array}{l}\text { F1a-12 } \\
\text { Fe } 10\end{array}$ \\
\hline
\end{tabular}




\begin{tabular}{|c|c|c|}
\hline & $\begin{array}{l}\text { everything again for all the activities, we were going to be unable to carry everything } \\
\text { out. So we decided to design only one activity, as you (the facilitators) recommended at } \\
\text { the beginning. Carrying out the whole design would be too much at the beginning." } \\
\text { D "Very useful tool (the ILDE). Very operative tool (more than Moodle)" } \\
\text { E "I'd prefer only one tool for implementation. But I understand it is necessary to reach } \\
\text { Moodle. So it is very useful." } \\
\text { F "The use of GLUE!-PS and WebCollage is burdensome. I don't understand very well } \\
\text { what is behind these tools. I'd like to have only one platform so that everything is } \\
\text { deployed into Moodle. You lose the track when you go into GLUE!-PS for making } \\
\text { modifications." } \\
\text { G [Teacher1]: "ILDE sharing functions, duplicate designs of others, etc... are very } \\
\text { useful" [Teacher2]: "In the workshop that was very difficult to me. Now (after the } \\
\text { follow-up), I find this much easier." } \\
\text { H "The use of shared documents allowed us to give feedback immediately. This allowed } \\
\text { the students to solve problems. They are more motivated now." } \\
\text { I "The students liked it a lot: see their group, what they are doing... and that we (the } \\
\text { teaching team) were able to see their work at the same time. They were more } \\
\text { supervised" } \\
\text { "Moodle worked flawlessly", } \\
\text { K Question: "Do you agree with the sentence: I have put into practice what I have learnt } \\
\text { during the workshop about learning design" (5 point Likert scale: 1=completely- } \\
\text { disagree, 5=completely agree). Answer: } 4 \\
\text { L "Among the advantages, you need to prepare it better, you have it much better } \\
\text { designed, much better planned, this is an advantage. This forces us, teachers, not to } \\
\text { improvise so much, and to have everything much better controlled. This facilitates a lot } \\
\text { the explanations you need to give to your students. " }\end{array}$ & $\begin{array}{l}\text { F1a-13 } \\
\text { F1a-13 } \\
\text { F1a-14 } \\
\text { F1a-15 } \\
\text { F1a-16 } \\
\text { F1a-17 } \\
\text { F1a-18 } \\
\text { F1a-20 } \\
\text { F1a-21 }\end{array}$ \\
\hline [Art-HE-Nursing] & $\begin{array}{l}\text { The enacted design was based on a concatenation of a jigsaw CL pattern (also known as } \\
\text { the puzzle pattern) and a peer-review pattern. }\end{array}$ & F1a-9 \\
\hline $\begin{array}{l}\text { [Diary-HE- } \\
\text { Nursing] }\end{array}$ & $\begin{array}{l}\text { A "I perceive the learning patterns employed in the course, used through ICTs such as } \\
\text { Moodle, as a way of carrying out things in a more planned way (and not designing the } \\
\text { lab work on the fly)." } \\
\text { B "It's difficult to understand the concept of going from WebCollage to GLUE!-PS } \\
\text { before launching it in Moodle". }\end{array}$ & $\begin{array}{l}\text { F1a-11 } \\
\text { F1a-14 }\end{array}$ \\
\hline [Int-HE-Telecom] & $\begin{array}{l}\text { A Question: "How many designs were you able to enact with students"? Answer: } \\
\text { "One". } \\
\text { B Question: "Rate your design in terms of" ( } 5 \text { point Likert scale: very low, low, neutral, } \\
\text { high, very high): Completeness (5), Originality (4), Complexity (1), Reusability (4) } \\
\text { C "For instance, for the last session, we've seen what to do to be sure that all students } \\
\text { reviewed the posters of the classmates, "forcing" them to post a comment. Something so } \\
\text { simple really worked well". } \\
\text { D "At the end, after the posters were presented, a debate started among us all (...) I } \\
\text { think it was very positive." } \\
\text { E "[Referring to how the designed situation was enacted with the students] I didn't } \\
\text { perceive any type of "resistance" from the students. They did it all without any problem. } \\
\text { They all could work in Moodle without any problem. I haven't received any type of } \\
\text { comment regarding any problem. In that sense, perfect. " } \\
F \text { "When everything was deployed into Moodle, everything went ok. You had the feeling } \\
\text { that everything was thoroughly planned. I had some concerns about potential delays in } \\
\text { the unfolding of the experience that could eventually affect other activities. There was a } \\
\text { critical moment when the network crashed. The students worked offline and all went } \\
\text { ok." } \\
{ }_{G} \text { Question: "Do you agree with the sentence: I have put into practice what I have learnt } \\
\text { during the workshop about learning design" (5 point Likert scale: 1=completely } \\
\text { disagree, 5=completely agree). Answer: } 5 \\
\mathrm{H} \text { "(the conceptualization tools) are useful since they help you to reflect in terms of } \\
\text { pyramid". }\end{array}$ & $\begin{array}{l}\text { F1a-8 } \\
\text { F1a-10 } \\
\text { F1a-11 } \\
\text { F1a-16 } \\
\text { F1a-17 } \\
\text { F1a-18 } \\
\text { F1a-20 } \\
\text { F1a-21 }\end{array}$ \\
\hline
\end{tabular}




\begin{tabular}{|c|c|c|}
\hline [Art-HE-Telecom] & The enacted design was based on a two-level pyramid CL pattern. & F1a-9 \\
\hline $\begin{array}{l}\text { [Obs-HE- } \\
\text { Telecom] }\end{array}$ & $\begin{array}{l}{[18 / 11 / 2014] \text { ILDE doubs tackled during the face-to-face meeting: URLs in }} \\
\text { WebCollage, tool reuse in Glue!-PS, WebCollage bug identification. }\end{array}$ & F1a-15 \\
\hline $\begin{array}{l}\text { [Maillog-HE- } \\
\text { Telecom] }\end{array}$ & $\begin{array}{l}{[08 / 01 / 2015] \text { "Yesterday it was the final session and I think it (went) very well. We }} \\
\text { projected the posters and they explained the posters and the truth is that debate heated } \\
\text { up afterwards. It looks like they (the students) liked the experience with the poster, so I } \\
\text { think we will do it again!" }\end{array}$ & F1a-17 \\
\hline [Int-HE-Geo] & $\begin{array}{l}\text { A Question: "How many designs were you able to enact with students"? Answer: } \\
\text { "One". } \\
\text { B Question: "Rate your design in terms of" ( } 5 \text { point Likert scale: very low, low, neutral, } \\
\text { high, very high): Completeness (5), Originality (5), Complexity (3), Reusability ( } 4 \text { ) } \\
{ }^{C} \text { Question: "Do you agree with the sentence: I have put into practice what I have learnt } \\
\text { during the workshop about learning design" (5 point Likert scale: } 1=\text { completely- } \\
\text { disagree, 5=completely agree). Answer: } 4 \\
\text { D "Very positive experience. The warming up was complicated, but not because of the } \\
\text { tools: I was "obliged " to reflect on the experience. " }\end{array}$ & $\begin{array}{l}\text { F1a-8 } \\
\text { F1a-10 } \\
\text { F1a-20 }\end{array}$ \\
\hline [Art-HE-Geo] & $\begin{array}{l}\text { The enacted design was based on a two-level pyramid CL pattern. The first level of that } \\
\text { pyramid embedded another two-level pyramid. }\end{array}$ & F1a-9 \\
\hline [Obs-HE-Geo] & $\begin{array}{l}\text { A [Meeting 10/10/2014] "I selected a jigsaw pattern... because in previous years, when } \\
\text { people were working cooperatively, their joint analysis were not that deep". } \\
\text { B [Meeting 04/11/2014] (discussion about doubts regarding the details of the jigsaw } \\
\text { pattern) "Why documents generated in a different jigsaw group should be reused? Why } \\
\text { should a document of the first activity be reused afterwards... when students can see it } \\
\text { in Moodle?" }\end{array}$ & F1a-11 \\
\hline [Maillog-HE-Geo] & $\begin{array}{l}\text { "[08/01/2015] Today (after Christmas holidays) we've got back to the project, and now } \\
\text { they (the students) are in the peer-review phase. Incredibly, they have followed the } \\
\text { delivery dates and all the agreed scheduled deadlines, and on Monday they will be able } \\
\text { to debate about the review generated by each team." }\end{array}$ & F1a-17 \\
\hline [Int-AE-English] & $\begin{array}{l}\text { A Question: "How many designs were you able to enact with students"? Answer: } \\
\text { "One". } \\
\text { B Question: "Rate your design in terms of" (5 point Likert scale: very low, low, neutral, } \\
\text { high, very high): Completeness (4), Originality (4), Complexity (5), Reusability (5) } \\
\text { C "...thinking of situations that could be a bit more flexible in terms of groups, I think it } \\
\text { is a very valid tool". } \\
\text { D "For me, the support of the implementation tool is very useful". } \\
\text { E "Then I starting to plan my activity, solving the technical issues of the ILDE, that we } \\
\text { solved here perfectly (in the face-to-face meetings)". } \\
\text { F "I came here (to the follow-up phase) because at the workshop I considered that the } \\
\text { idea was interesting, but I hadn't understood anything at all. It sounded greek to me. So } \\
\text { I enrolled (in the follow-up phase) to see what happened... because I had understood } \\
\text { nothing at all. I considered that CL, for language learning, might be very suitable, and } \\
\text { thus I enrolled. " } \\
\text { G "...so that was very positive for them. They liked a lot how the activity was planned. It } \\
\text { was sometimes burdensome for them, because each of them had to survey a lot of } \\
\text { information, in a language that was not theirs. But I think that, overall, in spite of all } \\
\text { the difficulties we had to overcome, the opinion of all of them was pretty positive." } \\
\mathrm{H} \text { "The students were not used to this type of work, not only because of the tools } \\
\text { (Moodle, Google presentation). They didn't know how to work in groups... depending } \\
\text { on others to carry out the work... I now realize that I thought I was using CL in my } \\
\text { classes... but I was wrong." } \\
\text { I "The students realized that many of the things they had devised, when they had to meet } \\
\text { again to carry out the last step (the jigsaw group activities), they realized that was not } \\
\text { what was requested, so they had to adjust,..." }\end{array}$ & $\begin{array}{l}\text { F1a-8 } \\
\text { F1a-10 } \\
\text { F1a-13 } \\
\text { F1a-13 } \\
\text { F1a-15 } \\
\text { F1a-15 } \\
\text { F1a-17 } \\
\text { F1a-19 } \\
\text { F1a-19 } \\
\text { F1a-20 }\end{array}$ \\
\hline
\end{tabular}




\begin{tabular}{|c|c|c|}
\hline & $\begin{array}{l}{ }^{J} \text { Question: "Do you agree with the sentence: I have put into practice what I have learnt } \\
\text { during the workshop about learning design" ( } 5 \text { point Likert scale: } 1=\text { completely } \\
\text { disagree, } 5=\text { completely agree). Answer: } 5 \\
\mathrm{~K} \text { "The ILDE itself at the beginning seemed to be super-difficult. Then you start to } \\
\text { control it and... I think it is a very good tool to create activities, not only in } \\
\text { technological terms, but rather it makes you really think, and consider whether an } \\
\text { activity you intend to carry out is pedagogically sound or rather whether it is useless." }\end{array}$ & F1a-21 \\
\hline [Art-AE-English] & $\begin{array}{l}\text { The enacted design was based on a jigsaw CL pattern (also known as the puzzle } \\
\text { pattern). }\end{array}$ & F1a-9 \\
\hline $\begin{array}{l}\text { [Maillog-AE- } \\
\text { English] }\end{array}$ & $\begin{array}{l}\text { [21/01/2015] (reporting on the second session of the learning situation with the } \\
\text { students) "Another positive point: at last the collaborative learning appeared. There } \\
\text { has been quite a lot of positive discussion in the group, even though they were the } \\
\text { experts (referring to the expert phase of the jigsaw employed for the situation). Thus, in } \\
\text { the next phase when they have to choose, the discussion will be richer and more } \\
\text { productive." }\end{array}$ & F1a-16 \\
\hline [Obs-AE-English] & $\begin{array}{l}\text { [Meeting } 21 / 10 / 2014] \text { [teacher] realizes in the end that some tasks were incorrect. For } \\
\text { instance, the pyramid was not the best choice for her case. [Facilitator2] explains what } \\
\text { the CL patterns are useful for, and the importance of creating the conditions so that } \\
\text { certain collaborative interactions happen. }\end{array}$ & F1a-12 \\
\hline [Int-AE-Ict] & 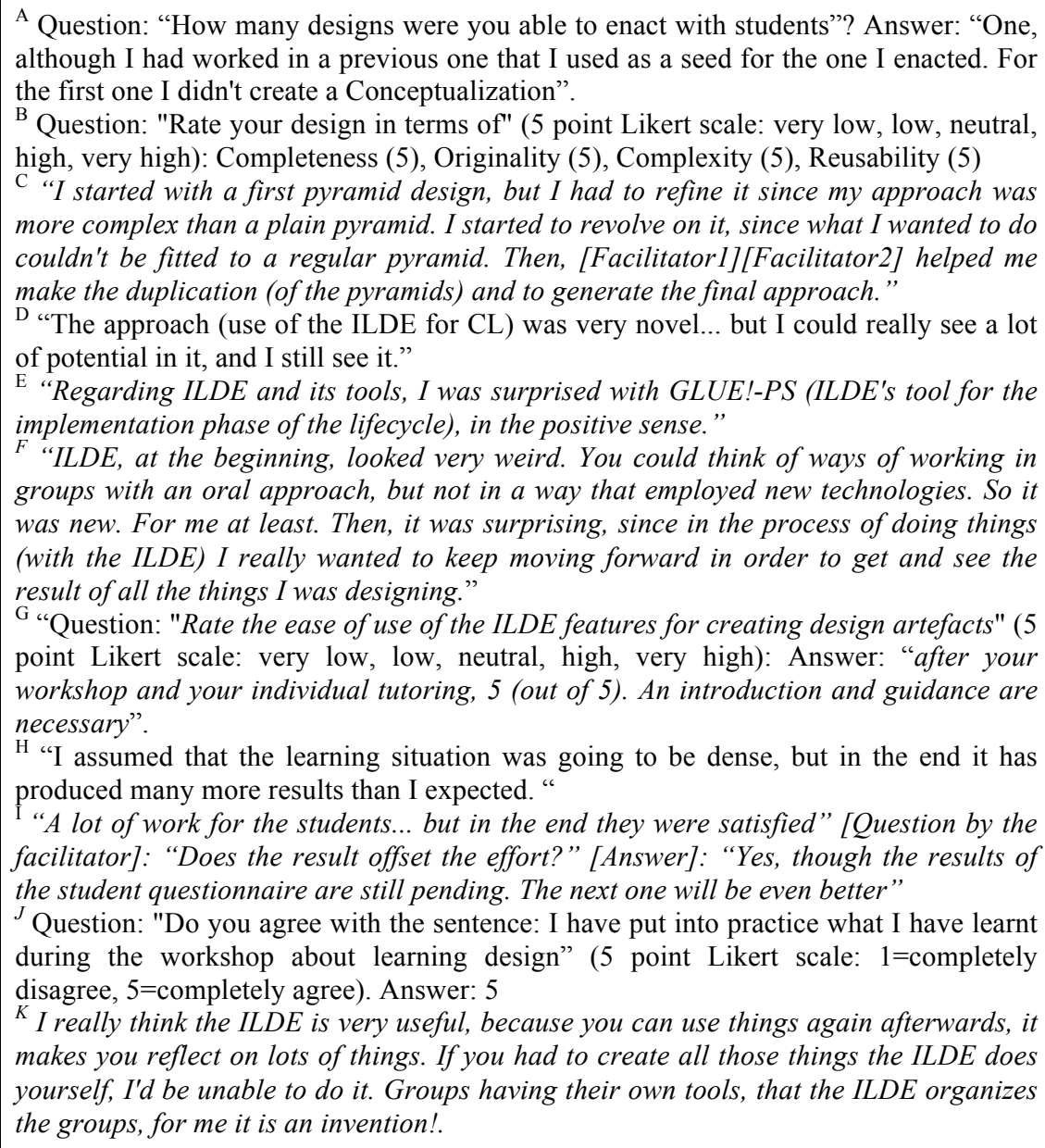 & $\begin{array}{l}\text { F1a-8 } \\
\text { F1a-10 } \\
\text { F1a-12 } \\
\text { F1a-13 } \\
\text { F1a-13 } \\
\text { F1a-14 } \\
\text { F1a-15 } \\
\text { F1a-16 } \\
\text { F1a-17 } \\
\text { F1a-21 } \\
\text { F1a-20 } \\
\text { F1a }\end{array}$ \\
\hline [Art-AE-Ict] & $\begin{array}{l}\text { The enacted design was based on a two-level pyramid CL pattern. Each level of the } \\
\text { pyramid embedded another two-level pyramid. }\end{array}$ & F1a-9 \\
\hline
\end{tabular}


[Diary-AE-Ict] [After reworking the implementation phase with GLUE!-PS due to some mistakes in F1a-15 the grouping of students] "Now, everything is ok. GLUE!-PS was easier to use than what I expected a priori".

Table A.4. Selected excerpts of evidence from the questionnaires delivered to the students participating in the enactments of the design teams for Subtopic T1a (ILDE's full-lifecycle support) in relation with the follow-up phase.

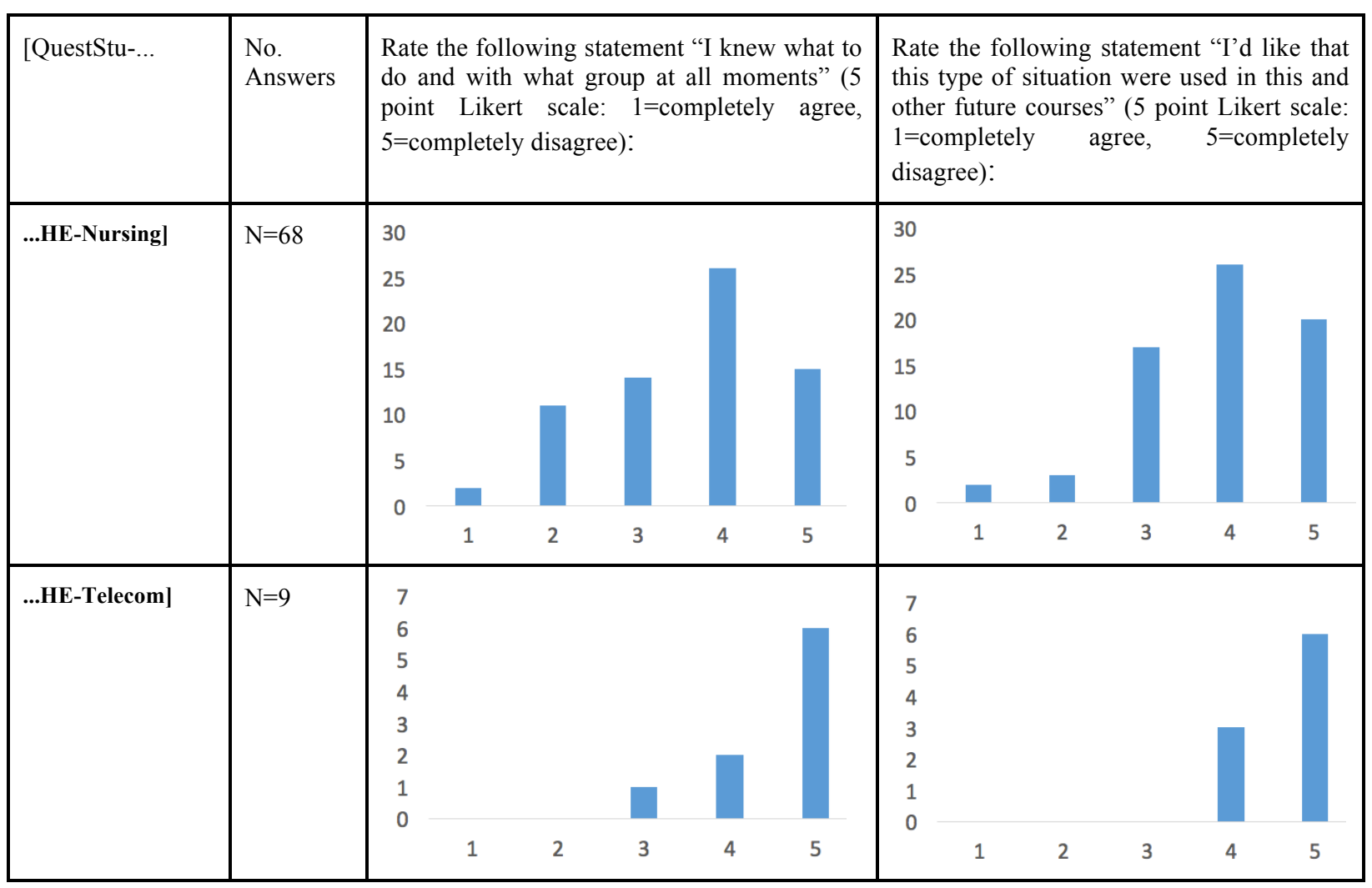




\begin{tabular}{|c|c|c|c|c|c|c|c|c|c|c|c|c|c|}
\hline ...HE-Geo] & $\mathrm{N}=12$ & $\begin{array}{l}7 \\
6 \\
5 \\
4 \\
3 \\
2 \\
1 \\
0\end{array}$ & 1 & 2 & 3 & 4 & 5 & $\begin{array}{l}7 \\
6 \\
5 \\
4 \\
3 \\
2 \\
1 \\
0\end{array}$ & $\begin{array}{c}0 \\
1 \\
1\end{array}$ & & 3 & 4 & 5 \\
\hline ...AE-English] & $\mathrm{N}=4$ & $\begin{array}{l}4 \\
3 \\
2 \\
1 \\
0\end{array}$ & 1 & 2 & 3 & 4 & 5 & $\begin{array}{l}5 \\
4 \\
3 \\
2 \\
1 \\
0\end{array}$ & 1 & 2 & 3 & 4 & 5 \\
\hline ...AE-Ict] & $\mathrm{N}=12$ & $\begin{array}{l}6 \\
5 \\
4 \\
3 \\
2 \\
1 \\
0\end{array}$ & 1 & 2 & 3 & 4 & 5 & $\begin{array}{r}10 \\
8 \\
6 \\
4 \\
2 \\
0\end{array}$ & 1 & 2 & . & 4 & 5 \\
\hline TOTAL & $\mathrm{N}=105$ & $\begin{array}{r}40 \\
30 \\
20 \\
10 \\
0\end{array}$ & . & 2 & 3 & 4 & 5 & $\begin{array}{r}50 \\
40 \\
30 \\
20 \\
10 \\
0\end{array}$ & $\begin{array}{l} \\
-1 \\
-\end{array}$ & $\frac{}{2}$ & 3 & 4 & $\frac{}{5}$ \\
\hline
\end{tabular}

Table A.5. Selected excerpts from [QuestPost-HE-WS] for Subtopic T1b (ILDE's community support) in relation with the workshop phase.

\begin{tabular}{|l|l|l|l|}
\hline $\begin{array}{l}\text { "Please, rate the } \\
\text { following ILDE } \\
\text { features" }(1=\mathrm{min}, \\
5=\max )\end{array}$ & $\begin{array}{l}\text { Number of } \\
\text { responses }\end{array}$ & Easiness & Helpfulness \\
\hline
\end{tabular}




\begin{tabular}{|c|c|c|c|c|c|c|c|c|c|c|c|c|c|}
\hline $\begin{array}{l}\text { Sharing a design with } \\
\text { other participants }\end{array}$ & 13 & $\begin{array}{l}5 \\
4 \\
3 \\
2 \\
1 \\
0\end{array}$ & & 2 & 3 & 4 & 5 & $\begin{array}{l}8 \\
7 \\
6 \\
5 \\
4 \\
3 \\
2 \\
1 \\
0\end{array}$ & 1 & 2 & 3 & 4 & 5 \\
\hline $\begin{array}{l}\text { Viewing the designs of } \\
\text { other participants }\end{array}$ & 12 & $\begin{array}{l}7 \\
6 \\
5 \\
4 \\
3 \\
2 \\
1 \\
0\end{array}$ & 1 & 2 & 3 & 4 & 5 & $\begin{array}{l}8 \\
6 \\
4 \\
2 \\
0\end{array}$ & 1 & 2 & - & 4 & 5 \\
\hline $\begin{array}{l}\text { Commenting on the } \\
\text { design of other } \\
\text { participants }\end{array}$ & 12 & $\begin{array}{l}7 \\
6 \\
5 \\
4 \\
3 \\
2 \\
1 \\
0\end{array}$ & 1 & 2 & 3 & 4 & 5 & $\begin{array}{l}7 \\
6 \\
5 \\
4 \\
3 \\
2 \\
1 \\
0\end{array}$ & 1 & 2 & 3 & 4 & 5 \\
\hline $\begin{array}{l}\text { Duplicating the designs } \\
\text { of other participants }\end{array}$ & 8 & $\begin{array}{l}4 \\
3 \\
2 \\
1 \\
0\end{array}$ & 1 & 2 & 3 & 4 & 5 & $\begin{array}{l}5 \\
4 \\
3 \\
2 \\
1 \\
0\end{array}$ & 1 & 2 & 3 & 4 & 5 \\
\hline
\end{tabular}

Table A.6. Selected excerpts of evidence supporting findings regarding Subtopic T1b (ILDE's community support) in relation with the follow-up phase.

\begin{tabular}{|l|l|l|}
\hline Data source & Excerpts & $\begin{array}{l}\text { Supported } \\
\text { Findings }\end{array}$ \\
\hline [Int-HE-Nursing] & $\begin{array}{l}\text { [Teacher1]: "ILDE sharing functions, duplicate designs of others, etc... are } \\
\text { very useful". [Teacher2]: "in the workshop that was very difficult to me. } \\
\text { Now (after the follow-up), I find this much easier." }\end{array}$ & F1b-1 \\
\hline$[$ Int-HE-Telecom] & $\begin{array}{l}\text { [Referring to the sharing features of the ILDE] "They were easy to use. } \\
\text { We've shared things with you (facilitators) and they were very easy." } \\
\text { [Facilitator] "and useful?" [Teacher] "Yes. We got the feedback from you" }\end{array}$ & F1b \\
\hline [Int-AE-English] & $\begin{array}{l}\text { "I've shared my designs with my colleague [name], but he never came back } \\
\text { to me. I also shared the designs with [name]. I think one of the good things of } \\
\text { this (the ILDE) is precisely that: I design an activity that can be useful for } \\
\text { you, you make an activity that can be useful for me." }\end{array}$ & F1b \\
\hline
\end{tabular}




\begin{tabular}{|l|l|l|}
\hline [Int-AE-Ict] & $\begin{array}{l}\text { [About social feature of the ILDE] "I think it is very interesting. I used it. All } \\
\text { I created is shared with you (the facilitators) and with [name] and [name], } \\
\text { read-only. It was easy to do it. And it is also very useful. Not only because of } \\
\text { the feedback from you (the facilitators). I also could follow what [name] was } \\
\text { doing." }\end{array}$ & \\
\hline [Maillog-HE-Geo] & $\begin{array}{l}\text { [17/10/2014] "The Narrative (conceptualization design artefact) is ready for } \\
\text { the Land Planning course. Its name is [name] and I shared it with you (the } \\
\text { facilitators) as editors. I'm waiting for your contributions, so as to improve it } \\
\text { and be able to enact it." }\end{array}$ & F1b \\
\hline [Diary-AE-English] & $\begin{array}{l}\text { [Referring to remote session 22/11/2014] "I resume the authoring phase, I've } \\
\text { read the comments posted by [one of the facilitators] in the ILDE. Although I } \\
\text { thank him for that, I'm a bit lost at the moment." }\end{array}$ & Fl \\
\hline [Diary-AE-Ict] & $\begin{array}{l}\text { [Referring to remote session 30/10/2014] "At around 20:00 I finished, saved } \\
\text { the WebCollage implementation. It took me 40 minutes approx. I shared it } \\
\text { with [the facilitators], [two of the AE teachers]" }\end{array}$ & F1b-2 \\
\hline
\end{tabular}

Table A.7. Selected excerpts of evidence supporting findings regarding Topic T2 (Affordability) in relation with the follow-up phase.

\begin{tabular}{|c|c|c|}
\hline Data source & Excerpts & $\begin{array}{l}\text { Supported } \\
\text { Findings }\end{array}$ \\
\hline [Int-HE-Nursing] & $\begin{array}{l}\text { AFacilitator] "Comment on the sentence: What I have learnt in the } \\
\text { workshop has speeded up my learning design activities" [Teacher] "I } \\
\text { needed to reflect a lot. It took much longer, with the advantage that in the } \\
\text { end it was more effective." } \\
\text { [Facilitator] "We had a lot of meetings and lot of work. Is it worth the } \\
\text { effort?" [Teacherl] "Yes. I felt very assured when planning the } \\
\text { assessment". [Teacher2]: "Next time it will be easier" } \\
\text { C [Facilitator]: "Do you save time thanks to the ILDE?" [Teacher]: "Yes, it } \\
\text { saved time thanks to the creation of the documents in the Moodle." }\end{array}$ & F2-1 \\
\hline [Int-HE-Telecom] & $\begin{array}{l}\text { [Facilitator] "Was it worth the effort of preparing the innovation?" } \\
\text { [Teacher1] "Yes, I think it was. The preparation effort took us longer. But it } \\
\text { is also true that when it comes to assessing, the effort is simpler. I don't have } \\
\text { to assess } 6 \text { reports. I have got the poster, I've seen them before and during } \\
\text { the last session, and I can now assess other things. So, yes, I think it is worth } \\
\text { the effort." [Teacher2]: "All we've done this year, the meeting with you and } \\
\text { all, will be useful for subsequent years. This year it took us } 20 \text { hours, maybe } \\
\text { next year with only } 2 \text { hours we have everything set up. The additional effort } \\
\text { for next years, I think, it is small." } \\
\\
\text { [Facilitator] "Comment on the sentence: What I have learnt in the } \\
\text { workshop has speeded up my learning design activities" [Teacher] "Had I } \\
\text { had to apply this from scratch, it would have taken me much longer". }\end{array}$ & $\begin{array}{l}\text { F2-1, F2-2 } \\
\text { F2-4 } \\
\text { F }\end{array}$ \\
\hline [Maillog-HE-Geo] & $\begin{array}{l}\text { A08/01/2015] "I'm finishing the diary, and I'll express my opinion and } \\
\text { everything that happened. But, beyond having worked very hard back in } \\
\text { October, and especially after having rethought again many of the things I } \\
\text { considered as established and they weren't that much, I believe that the } \\
\text { outcome has been very good." } \\
B \text { [20/11/2014] "I revisited groups and reviewers, and although the tasks for } \\
\text { each students were properly defined, they were a bit confusing. I changed } \\
\text { the names in GLUE!PS and now it is much clearer". }\end{array}$ & F2-3 \\
\hline
\end{tabular}




\begin{tabular}{|c|c|c|}
\hline & $\begin{array}{l}\text { "[17/11/2014] "I decided to revisit the implementation, and I've done a new } \\
\text { one... I reduced some file names and I changed other labels so that, when } \\
\text { the students go to Moodle, the descriptions are representative, but not } \\
\text { messy". }\end{array}$ & F2-3 \\
\hline [Int-AE-English] & $\begin{array}{l}\text { A "After the (training) workshop, I thought it was very interesting. I decided } \\
\text { to collaborate with you (the facilitators/researchers). The elaboration } \\
\text { process (i.e. the follow-up phase) was very difficult at the beginning. I was } \\
\text { starting from scratch in terms of informatics skills. I didn't know what a } \\
\text { GoogleDocs was. I had no idea about Google Presentations. In addition to } \\
\text { the complexity of the activity itself, I had to get ready for all that stuff, get up } \\
\text { to date with all those tools. The truth is that with a lot of effort I managed to } \\
\text { understand what we were doing." } \\
\text { B "I finished the activity, I was very satisfied, with lots and lots of work from } \\
\text { my side, but very satisfied in the end." }\end{array}$ & F2-1 \\
\hline [Int-AE-Ict] & $\begin{array}{l}\text { A "It was like a "roller coaster". Initially, it was in an uphill climb, i.e. } \\
\text { adopting the pedagogical approach, designing, looking at variants, and } \\
\text { paying attention to the change of Moodle servers. Then, it was going down } \\
\text { (technical problems, not being able to supervise adequately the students } \\
\text { work, being unable to continue on time). Then, it was again going up, the } \\
\text { finalization of everything, that left a good impression - taste, mainly due to } \\
\text { the reaction of the students. At a personal level, all the troubles, bad } \\
\text { moments when things were not working as expected, when I had to make } \\
\text { implementations again, were compensated by the interest, the enthusiasm, } \\
\text { and the dedication and commitment shown by the students. It is true that I } \\
\text { motivated them...but they engaged in a praiseworthy way. They were the } \\
\text { ones that didn't want to miss any detail, finish everything. In fact I didn't } \\
\text { allow them to do so since the activities were getting stretched too much." } \\
\text { B "My initial fears (regarding the use of ILDE implementation functions) } \\
\text { were found to be false, it was not difficult, due to several iterations that I } \\
\text { made; simply, the elements were structured differently", }\end{array}$ & F2-1 \\
\hline [Obs-AE-Ict] & $\begin{array}{l}\text { [Meeting 13/11/2014] [Facilitator] explains how to configure tool instances } \\
\text { with GLUE!-PS (implementation tool within the ILDE). [Teacher] says: } \\
\text { "This is much easier than with Moodle!" }\end{array}$ & F2-4 \\
\hline
\end{tabular}

Table A.8. Selected excerpts of evidence for Topic T2 (Affordability) in relation with the time devoted by the participants to face-to-face meetings, as well as to remote work using the ILDE, during the follow-up phase.

\begin{tabular}{|l|l|l|}
\hline Design Team (data sources) & $\begin{array}{l}\text { Number of face-to-face meetings with } \\
\text { Facilitators (and approximate total } \\
\text { duration) }\end{array}$ & $\begin{array}{l}\text { Reported hours of remote work in the } \\
\text { design (adding the hours by } \\
\text { individual teachers in each team) }\end{array}$ \\
\hline$[$ Diary-HE-Nursing $]$ & $5(7,5 \mathrm{~h})$ & $8 \mathrm{~h}$ \\
\hline $\begin{array}{l}{[\text { Diary-HE-Telecom }]} \\
{[\text { Obs-HE-Telecom }]}\end{array}$ & $4(4 \mathrm{~h})$ & $4,5 \mathrm{~h}$ \\
\hline$[$ Obs-HE-Geo $]$ & $3(3,5 \mathrm{~h})$ & $30 \mathrm{~h}$ \\
\hline $\begin{array}{l}{[\text { Diary-AE-English }]} \\
{[\text { Obs-AE-English }]}\end{array}$ & $8(10,5 \mathrm{~h})$ & $15 \mathrm{~h}$ \\
\hline $\begin{array}{l}{[\text { Diary-AE-Ict }]} \\
{[\text { Obs-AE-Ict }]}\end{array}$ & $5(6,5 \mathrm{~h})$ & $12,5 \mathrm{~h}$ \\
\hline
\end{tabular}


Table A.9. Selected excerpts of evidence supporting findings regarding Topic T3 (Perception about adoption) in relation with the follow-up phase.

\begin{tabular}{|c|c|c|}
\hline Data source & Excerpts & $\begin{array}{l}\text { Supported } \\
\text { Findings }\end{array}$ \\
\hline [Int-HE-Nursing] & $\begin{array}{l}\text { A "In the second semester we'd like to use the ILDE". } \\
\text { B "I changed habits in my life. Now I use the word "share". We now use sharing } \\
\text { support (Google Drive) even outside the classroom." } \\
\text { C Rate your agreement with the following statements (1-5 Likert scale: I=very } \\
\text { low, } 5=\text { very high): } \\
\text { - I think what I have learnt in this experience can be applied to/used in my } \\
\text { - work in the future. Answer: } 4 \text {. } \\
\text { - I think the ILDE could be adopted on a larger scale at my institution in } \\
\text { - } \text { the future. Answer: } 4 \text {. } \\
\text { - I think the ILDE fits the needs of my work sector at large. Answer: } 4 \text {. ILDE-supported TPD program could be proposed on a larger } \\
\text { - } \text { scale at my institution in the future. Answer: } 5 \text {. } \\
\text { I think the ILDE-supported TPD program fits the need of my work } \\
\text { sectorge. Answer: } 5 \text {. }\end{array}$ & F3-1 \\
\hline [Maillog-HE-Telecom] & $\begin{array}{l}\text { A }[08 / 01 / 2015] \text { "Yesterday it was the final session and I think it (went) very well. } \\
\text { We projected the posters and they explained the posters and the truth is that } \\
\text { debate heated up afterwards. It looks they (the students) liked the experience with } \\
\text { the poster, so I think we will do it again!" }\end{array}$ & F3-1 \\
\hline [Int-HE-Telecom] & $\begin{array}{l}\text { Rate your agreement with the following statements (1-5 Likert scale: } 1=\text { very } \\
\text { low, } 5=\text { very high): } \\
\text { - I think what I have learnt in this experience can be applied to/used in my } \\
\text { work in the future. Answer: } 5 \text {. } \\
\text { - I think the ILDE could be adopted on a larger scale at my institution in } \\
\text { the future. Answer: } 3 \text {. "In the sense that I think it is very useful, but I } \\
\text { cannot find it easy for the institution to put it into practice" } \\
\text { - I think the ILDE fits the needs of my work sector at large. Answer: } 4 . \\
\text { "Yes, it does. These models are very convenient" } \\
\text { - I think the ILDE-supported TPD program could be proposed on a larger } \\
\text { scale at my institution in the future. Answer: } 5 \text {. } \\
\text { I think the ILDE-supported TPD program fits the need of my work } \\
\text { sector at large. Answer: } 5 \text {. "I think it was very interesting. I used it and } \\
\text { I liked it." }\end{array}$ & F3-2 \\
\hline [Int-HE-Geo] & $\begin{array}{l}\text { A "It is worth the effort (both pedagogically and technologically). Additionally, the } \\
\text { aspect of of reflection is important: you stop giving for granted certain aspects of } \\
\text { your teaching. I'd be happy to use the ILDE again for my teaching!" } \\
{ }^{B} \text { Rate your agreement with the following statements (1-5 Likert scale: I=very low, } \\
5=\text { very high): } \\
\text { - I think what I have learnt in this experience can be applied to/used in my } \\
\text { work in the future. Answer: } 5 \text {. } \\
\text { - I think the ILDE could be adopted on a larger scale at my institution in } \\
\text { the future. Answer: } 5 \text {. } \\
\text { - I think the ILDE fits the needs of my work sector at large. Answer: } 5 \text {. } \\
\text { - I think the ILDE-supported TPD program could be proposed on a larger } \\
\text { scale at my institution in the future. Answer: } 4 \text {. } \\
\text { - I think the ILDE-supported TPD program fits the need of my work } \\
\text { sector at large. Answer: } 5 \text {. }\end{array}$ & F3-1, F3-3 \\
\hline [Int-AE-English] & $\begin{array}{l}\text { [Facilitator]: "Would you recommend the experience to other colleagues?" } \\
\text { [Teacher]: "Without any doubt, in spite of the problems and the effort". } \\
\text { [Facilitator]: "Would you consider repeating the experience?" [Teacher]: "Yes, I }\end{array}$ & F3-1 \\
\hline
\end{tabular}




\begin{tabular}{|c|c|c|}
\hline & $\begin{array}{l}\text { plan to repeat it with new designs during the following academic year". } \\
\text { B "I'd like to carry out another design, to see if my perceptions about what is easy } \\
\text { or difficult (about the ILDE) changes. I'm sure it will. At the beginning it was very, } \\
\text { very difficult. I didn't even know what Moodle was, I knew nothing. I didn't know } \\
\text { where we'd get to. " } \\
\text { c Rate your agreement with the following statements (1-5 Likert scale: I=very low, } \\
\text { 5=very high): } \\
\text { - I think what I have learnt in this experience can be applied to/used in my } \\
\text { - work in the future. Answer: } 5 \\
\text { I think the ILDE could be adopted on a larger scale at my institution in } \\
\text { the future. Answer: 5. "I think it can be adopted. What needs to be } \\
\text { changed is that other colleagues do want to use it." } \\
\text { - I think the ILDE fits the needs of my work sector at large. Answer: } 4 \\
\text { - I think the ILDE-supported TPD program could be proposed on a larger } \\
\text { scale at my institution in the future. Answer: } 5 \text {. "It can also be used by } \\
\text { social workers. Some of the attitudes should be changed". } \\
\text { - I think the ILDE-supported TPD program fits the need of my work } \\
\text { sector at large. Answer: } 4 \text {. "The 4-hour workshop was too short". }\end{array}$ & F3-1 \\
\hline [Int-AE-Ict] & $\begin{array}{l}\text { A [Facilitator]: "Would you recommend the experience to other colleagues?" } \\
\text { [Teacher]: "Of course, but indicating that it has a cost, you have to work; you } \\
\text { have to question yourself constantly; that feedback is needed; and that this cannot } \\
\text { be done in a single session." } \\
\text { B Rate your agreement with the following statements (1-5 Likert scale: I=very } \\
\text { low, 5=very high): } \\
\text { - I think what I have learnt in this experience can be applied to/used in my } \\
\text { work in the future. Answer: } 5 \\
\text { - I think the ILDE could be adopted on a larger scale at my institution in } \\
\text { the future. Answer: } 5 \text {. "I wish it could happen!. I think it can be } \\
\text { adopted. Were it adopted, I wouldn't have had to follow this course, new } \\
\text { educative goals would have been achieved. I see it completely feasible." } \\
\text { - I think the ILDE fits the needs of my work sector at large. Answer: } 4 \\
\text { - I think the ILDE-supported TPD program could be proposed on a larger } \\
\text { scale at my institution in the future. Answer: } 5 \\
\text { I think the ILDE-supported TPD program fits the need of my work } \\
\text { sector at large. Answer: } 5 \text {.Yes, it does, with some adaptations. There } \\
\text { will be some reluctance from some colleagues to adopt it. Some students } \\
\text { will be reluctant also to the use of ICT." }\end{array}$ & $\begin{array}{l}\text { F3-1, F3-3 } \\
\text { F3-2 } \\
\end{array}$ \\
\hline
\end{tabular}

